\title{
Primary and secondary sources of ambient formaldehyde in the Yangtze River Delta based on Ozone Mapping and Profiler Suite (OMPS) observations
}

\author{
Wenjing Su${ }^{1}$, Cheng Liu ${ }^{1,2,3,4,5}$, Qihou $\mathrm{Hu}^{2}$, Shaohua Zhao ${ }^{6}$, Youwen $\mathrm{Sun}^{2}$, Wei Wang ${ }^{2}$, Yizhi Zhu ${ }^{2}$, Jianguo Liu ${ }^{2,3}$, \\ and Jhoon $\mathrm{Kim}^{7}$ \\ ${ }^{1}$ School of Earth and Space Sciences, University of Science and Technology of China, Hefei, 230026, China \\ ${ }^{2}$ Key Lab of Environmental Optics \& Technology, Anhui Institute of Optics and Fine Mechanics, \\ Chinese Academy of Sciences, Hefei, 230031, China \\ ${ }^{3}$ Center for Excellence in Regional Atmospheric Environment, Institute of Urban Environment, \\ Chinese Academy of Sciences, Xiamen, 361021, China \\ ${ }^{4}$ Key Laboratory of Precision Scientific Instrumentation of Anhui Higher Education Institutes, \\ University of Science and Technology of China, Hefei, 230027, China \\ ${ }^{5}$ Anhui Province Key Laboratory of Polar Environment and Global Change, USTC, Hefei, 230026, China \\ ${ }^{6}$ Satellite Environment Center, State Environmental Protection Key Laboratory of Satellite Remote Sensing, \\ Ministry of Ecology and Environment, Beijing, 100094, China \\ ${ }^{7}$ Department of Atmospheric Sciences, Yonsei University, Seoul, 03722, South Korea
}

Correspondence: Cheng Liu (chliu81@ustc.edu.cn) and Qihou Hu (qhhu@aiofm.ac.cn)

Received: 13 November 2018 - Discussion started: 2 January 2019

Revised: 3 April 2019 - Accepted: 16 April 2019 - Published: 20 May 2019

\begin{abstract}
Formaldehyde (HCHO) in the ambient air not only causes cancer but is also an ideal indicator of volatile organic compounds (VOCs), which are major precursors of ozone $\left(\mathrm{O}_{3}\right)$ and secondary organic aerosol (SOA) near the surface. It is meaningful to differentiate between the direct emission and the secondary formation of $\mathrm{HCHO}$ for $\mathrm{HCHO}$ pollution control and sensitivity studies of $\mathrm{O}_{3}$ production. However, understanding of the sources of HCHO is still poor in China, due to the scarcity of field measurements (both spatially and temporally). In this study, tropospheric HCHO vertical column densities (VCDs) in the Yangtze River Delta (YRD), East China, where HCHO pollution is serious, were retrieved from the Ozone Mapping and Profiler Suite (OMPS) onboard the Suomi National Polar-orbiting Partnership (Suomi-NPP) satellite from 2014 to 2017; these retrievals showed good agreement with the tropospheric $\mathrm{HCHO}$ columns measured using ground-based high-resolution Fourier transform infrared spectrometry (FTS) with a correlation coefficient $(R)$ of 0.78. Based on these results, the cancer risk was estimated both nationwide and in the YRD region. It was calculated that at least 7840 people in the YRD region would develop cancer
\end{abstract}

in their lives due to outdoor $\mathrm{HCHO}$ exposure, which comprised $23.4 \%$ of total national cancer risk. Furthermore, the contributions of primary and secondary sources were apportioned, in addition to primary and secondary tracers from surface observations. Overall, the $\mathrm{HCHO}$ from secondary formation contributed most to ambient $\mathrm{HCHO}$ and can be regarded as the indicator of VOC reactivity in Hangzhou and in urban areas of Nanjing and Shanghai from 2015 to 2017, due to the strong correlation between total $\mathrm{HCHO}$ and secondary HCHO. At industrial sites in Nanjing, primary emissions more strongly influenced ambient HCHO concentrations in 2015 and showed an obvious decreasing trend. Seasonally, HCHO from secondary formation reached a maximum in summer and a minimum in winter. In the spring, summer, and autumn, secondary formation had a significant effect on the variation of ambient $\mathrm{HCHO}$ in urban regions of Nanjing, Hangzhou, and Shanghai, whereas in the winter the contribution from secondary formation became less significant. A more thorough understanding of the variation of the primary and secondary contributions of ambient $\mathrm{HCHO}$ is needed to develop a better knowledge regarding the role 
of $\mathrm{HCHO}$ in atmospheric chemistry and to formulate effective control measures to decrease $\mathrm{HCHO}$ pollution and the associated cancer risk.

\section{Introduction}

In recent years, air pollution has become increasingly serious in China (Tang et al., 2012; Shi et al., 2014; Rohde and Muller, 2015), and it currently poses a grievous risk to human health (Wang and Mauzerall, 2006). Previous studies have indicated that air pollution has killed more people worldwide than tuberculosis, AIDS, breast cancer, and malaria (Yang et al., 2013; World Health Organization, 2014a, b). According to the US Environmental Protection Agency (EPA), HCHO has been identified as the major carcinogen among the 187 hazardous air pollutants (HAPs), and exposure to levels as low as $1 \mu \mathrm{g} \mathrm{m}^{-3}$ (about $0.7 \mathrm{ppb}$ at standard temperature and pressure) of $\mathrm{HCHO}$ over a human lifetime could cause up to 13 in every million people to develop lung and nasopharyngeal cancer (Zhu et al., 2017a). HCHO not only directly affects public health but also plays a significant role in atmospheric photochemistry (Levy, 1971). The photolysis of HCHO leads to the production of the $\mathrm{HO}_{x}$ radical $\left(\mathrm{OH}+\mathrm{HO}_{2}\right)$ and subsequently affects the oxidative capacity of the atmosphere (Volkamer et al., 2010). Moreover, $\mathrm{HCHO}$ may contribute to $\mathrm{O}_{3}$ pollution via photochemical reactions (Haagen-Smit, 1950; Carter, 1994; Russell et al., 1995), which favor the formation of secondary organic aerosol (SOA) by providing the $\mathrm{OH}$ radical (Yang et al., 2018). Therefore, monitoring and controlling the ambient $\mathrm{HCHO}$ concentration are of great significance for public health.

$\mathrm{HCHO}$ can be directly emitted into the atmosphere from biogenic sources, such as biomass burning and vegetation (Lee et al., 1997; Finlayson-Pitts and Pitts, 1999; Holzinger et al., 1999; Andreae and Merlet, 2001), and anthropogenic activities, such as vehicles emissions, industrial emissions, and coal combustion (Carlier et al., 1986; Williams et al., 1990; Hoekman, 1992; Carter, 1995; Anderson et al., 1996; Kean et al., 2001; Klimont et al., 2002; Reyes et al., 2006; Wei et al., 2008; Wang et al., 2013; Dong et al., 2014; Liu et al., 2017). The direct emission of HCHO is mainly due to incomplete combustion and is closely related to the emission of $\mathrm{CO}$. Furthermore, $\mathrm{HCHO}$ can be formed from the atmospheric oxidation of volatile organic compounds (VOCs) (Altshuller, 1993; Carter, 1995; Seinfeld and Pandis, 2016) which also leads to the formation of $\mathrm{O}_{3}$ (Levy, 1971; Crutzen, 1979; Warneke et al., 2004; Duan et al., 2008). In order to effectively control $\mathrm{HCHO}$ concentrations and improve air quality, it is necessary to determine the primary emission sources and secondary formation pathways of ambient $\mathrm{HCHO}$.

In previous studies, the ratio of the Ozone Monitoring Instrument (OMI) tropospheric column of $\mathrm{HCHO}$ and $\mathrm{NO}_{2}$ have been used as indicators of the sensitivity regime of $\mathrm{O}_{3}$ formation (Duncan et al., 2010; Witte et al., 2011; Liu et al., 2016; Su et al., 2017), under the assumption that HCHO is a proxy for the reactivity of VOCs. Secondary HCHO is produced with the formation of peroxy radicals $\left(\mathrm{RO}_{2}\right)$, and is therefore positively correlated with $\mathrm{RO}_{2}$; thus, it can be identified as a proxy for total VOC reactivity (Carter, 1994). Therefore, strictly speaking, only the HCHO concentration that stems from secondary formation can be used to analyze the sensitivity regime of $\mathrm{O}_{3}$ production, combined with the $\mathrm{NO}_{2}$ concentration. As secondary formation is the dominant source of HCHO on a global scale (De Smedt et al., 2008), total $\mathrm{HCHO}$ is usually adopted to replace secondary $\mathrm{HCHO}$ as the indicator of total VOC reactivity. However, in some regions that are subject to strong human activities, the contribution of primary emissions to ambient $\mathrm{HCHO}$ cannot be ignored (Ma et al., 2016). Hence, the separation of secondary $\mathrm{HCHO}$ from primary $\mathrm{HCHO}$ would be favorable to develop a better understanding of $\mathrm{O}_{3}$ formation sensitivity, especially in urban areas.

Previous studies have attempted to identify contributions to ambient $\mathrm{HCHO}$ from direct emission and secondary formation via the used of linear multiple regression analysis. Because of the strong relation between primary $\mathrm{HCHO}$ and $\mathrm{CO}$ emission and the formation of $\mathrm{HCHO}$ and $\mathrm{O}_{3}$ from the oxidation of VOCs, $\mathrm{CO}$ and $\mathrm{O}_{3}$ can be used as the respective tracers for primary emission and secondary formation of $\mathrm{HCHO}$. Several studies have been carried out on primary and secondary sources of $\mathrm{HCHO}$ using the $\mathrm{CO}-\mathrm{O}_{3}$ tracer pair. For instance, contributions from primary and secondary sources to ambient $\mathrm{HCHO}$ were characterized by statistical analogy to $\mathrm{CO}$ and $\mathrm{O}_{3}$ in Houston, TX in the summer of 2000 (Friedfeld et al., 2002), in Beijing during the 2008 Olympic Games (Li et al., 2010), and in Hong Kong from winter of 2012 to autumn of 2013 (Lui et al., 2017). Hong et al. (2018) estimated contributions from primary emission and secondary formation to HCHO measured by MAX-DOAS using the $\mathrm{CO}-\mathrm{O}_{x}\left(\mathrm{O}_{3}+\mathrm{NO}_{2}\right)$ tracer pair which was measured by the Sensor Networks for Air Quality (SNAQ) in the winter of 2015 in Yangtze River Delta. Garcia et al. (2006) indicated that using the $\mathrm{CO}-\mathrm{CHOCHO}$ tracer pair to separate different sources of $\mathrm{HCHO}$ was more reasonable than using $\mathrm{CO}-\mathrm{O}_{3}$ because $\mathrm{CHOCHO}$ has a similar atmospheric lifetime to HCHO. However, continuous observations of CHO$\mathrm{CHO}$ are unfortunately not available.

Previous studies have often concentrated on contributions from different sources at one specific site and within a short time period; this is due to the constraints of available measurements of $\mathrm{HCHO}$ and its tracers with respect to primary emissions and secondary formation. In China, $\mathrm{CO}$ and $\mathrm{O}_{3}$ measurements can be obtained from the China National Environmental Monitoring Center (CNEMC) network. However, $\mathrm{HCHO}$ is not measured at these stations. There are various analytical methods available to measure HCHO concentrations, including the following: Fourier transform in- 
frared spectroscopy (FTIR; Lawson et al., 1990); differential optical absorption spectroscopy (DOAS; Platt and Perner, 1980); tunable diode laser absorption spectroscopy (TDLAS); the 2,4-dinitrophenylhydrazine (DNPH) method, in which HCHO is captured using DNPH and then analyzed by high-performance liquid chromatography (HPLC; Fung and Grosjean, 1981); and proton transfer reaction mass spectrometry (PTR-MS; Karl et al., 2003). Nevertheless, it is difficult to perform long-term observations of the HCHO concentration over a wide area using ground-based measurements. However, long-term information regarding ambient $\mathrm{HCHO}$ on a global scale can be accessibly obtained from spacebased remote sensors such as Global Ozone Monitoring Experiment (GOME; Martin et al., 2004), the Scanning Imaging Absorption Spectrometer for Atmospheric Chartography (SCIAMACHY; Bovensmann et al., 1999), the GOME2 instruments (De Smedt et al., 2012, 2015), the Ozone Monitoring Instrument (OMI; González Abad et al., 2015), the Ozone Mapping and Profiler Suite (OMPS; C. Li et al., 2015; González Abad et al., 2016) and the TROPOspheric Monitoring Instrument (TROPOMI; De Smedt et al., 2018). However, HCHO observations from SCIAMACHY and TROPOMI are only available until 2011 (Shah et al., 2018) and after October 2017, respectively; the GOME2A instrument suffers degradation issues (De Smedt et al., 2012); OMI observations are easily affected by the instrumental "row anomaly" (González Abad et al., 2015); and the spatial $(80 \mathrm{~km} \times 40 \mathrm{~km})$ and temporal (within $1.5 \mathrm{~d}$ ) resolution of GOME-2B is even lower than OMPS (Munro et al., 2016). After considering the long-term record and data quality, $\mathrm{HCHO}$ observations from OMPS were adopted in this study. Due to the low global coverage of the Tropospheric Emission Spectrometer (Aura-TES; Luo et al., 2002, 2007) and the increasing noise of the Atmospheric InfraRed Sounder (Aqua-AIRS) after 2004 (Pagano et al., 2012), which both measure tropospheric CO in close temporal proximity to the OMPS observations, obtaining a precise CO concentration in the YRD after 2013 from satellite data was difficult. Therefore, $\mathrm{CO}$ and $\mathrm{O}_{3}$ concentrations at the surface, simultaneously monitored by the China National Environmental Monitoring Center (CNEMC) network, were used in this study.

In this paper, we focus on contributions from primary and secondary sources to ambient HCHO from 2015 to 2017 in Nanjing (the capital of Jiangsu Province), Hangzhou (the capital of Zhejiang Province) and Shanghai; these are all megacities in the YRD region and have populations of more than 8 million people. The YRD region is located on the alluvial plains where the Yangtze River drains into the East China Sea, and consists of Jiangsu and Zhejiang provinces and the Shanghai municipality. The YRD region is one of the most important economic areas in China and is also a rapidly developing industrial sector. Along with the very rapid development of economy and industry, the YRD region is currently suffering from serious air pollution $(\mathrm{H}$. Li et al., 2015;
Gao et al., 2016; T. Wang et al., 2017; Wang et al., 2018). Details regarding the measurement of specific air pollutants are described in Sect. 2, whereas the spatiotemporal distribution of HCHO VCDs in the YRD region, as well as the contributions from primary and secondary sources to ambient $\mathrm{HCHO}$ are shown in Sect. 3.

\section{Measurements and methodology}

\subsection{OMPS HCHO observation}

The Ozone Mapping and Profiling Suite Nadir Mapper (OMPS-NM), which is one of the OMPS suite of instruments, was launched on 28 October 2011 onboard the Suomi National Polar-orbiting Partnership (Suomi-NPP) satellite. The Suomi-NPP is a polar sun-synchronous satellite with an average altitude of $824 \mathrm{~km}$ (Flynn et al., 2014). It crosses the Equator each afternoon at about 13:30 LT (local time) on the ascending node. The OMPS-NM combines a single grating and a $340 \times 740$ pixel charge-coupled device $(\mathrm{CCD})$ detector to measure UV radiation every $0.42 \mathrm{~nm}$ from 300 to $380 \mathrm{~nm}$ with a $1.0 \mathrm{~nm}$ full width at half maximum (FWHM) resolution. A recent analysis showed that the OMPS-NM sensor has a signal-to-noise ratio of $2000: 1$ or better within the wavelength range of 320 to $370 \mathrm{~nm}$ (Seftor et al., 2014). It has a $110^{\circ}$ cross-track field of view (FOV) providing high temporal (daily global coverage) resolution, and measurements are combined into 35 cross-track bins giving a spatial resolution of $50 \mathrm{~km} \times 50 \mathrm{~km}$ in OMPS-NM standard Earth science mode. The OMPS-NPP Nadir Mapper Earth View Level 1B data, available at https://search.earthdata.nasa.gov (last access: 8 May 2019), were downloaded to retrieve the HCHO slant column density (SCD). Details regarding the fitting settings for the HCHO SCD retrieval are given in González Abad et al. (2016). In this study, the vertical profiles of HCHO from WRF-Chem modeling were used to calculate the air-mass factor (AMF). The model configuration was described in detail in our previous study (Su et al., 2017). Finally, the HCHO VCD was calculated using the AMF as follows:

$\mathrm{VCD}=\frac{\mathrm{SCD}}{\mathrm{AMF}}$

\subsection{FTS tropospheric HCHO column measurement}

The ground-based FTS instrument, located west of Hefei $\left(117.17^{\circ} \mathrm{E}, 31.9^{\circ} \mathrm{N}\right)$, is a candidate station for the Network for Detection of Atmospheric Composition Change (NDACC, http://www.ndacc.org/, last access: 8 May 2019). The global NDACC can perform simultaneous retrieval of mixing ratio profiles for trace gases, such as $\mathrm{O}_{3}, \mathrm{CO}, \mathrm{CH}_{4}$, $\mathrm{NO}_{2}$, and HCHO, using FTS (Kurylo, 1991; Notholt et al., 1995; Vigouroux et al., 2009), and the retrieval results have been widely used for atmospheric chemistry research and the validation of satellite observations (Yuan et al., 2015; Sun et 
al., 2017; W. Wang et al., 2017; Tian et al., 2018; Sun et al., 2018). The observation system consists of a high-resolution Fourier transform spectrometer (IFS 125HR), a solar tracker (Tracker-A solar 547), and a weather station (ZENO-3200). The FTS solar spectra measurements were performed over a broad spectral range from 600 to $4500 \mathrm{~cm}^{-1}$ with a spectral resolution of $0.005 \mathrm{~cm}^{-1}$, and the $\mathrm{HCHO}$ spectra were recorded in the range from 2400 to $3310 \mathrm{~cm}^{-1}$. The vertical profile of HCHO was retrieved using the SFIT4 algorithm (version 0.9.4.4). Detailed retrieval settings for $\mathrm{HCHO}$ are listed in Sun et al. (2018). Daily a priori profiles of pressure, temperature, and $\mathrm{H}_{2} \mathrm{O}$ are obtained from the National Centers for Environmental Protection and the National Center for Atmospheric Research (NCEP/NCAR) reanalysis. And a priori profiles of $\mathrm{HCHO}$ and its interfering gases were taken from a dedicated Whole Atmosphere Community Climate Model (WACCM). For HCHO observation, the four microwindows (MW) which are centered at around $2770 \mathrm{~cm}^{-1}$ were selected for satellite validation, and a de-weighting signal-to-noise ratio (SNR) of 600 was used. The instrument line shape (ILS) is described by analyzing $\mathrm{HBr}$ cell spectra using LINEFIT14.5 software. Finally the tropospheric HCHO partial column was calculated by integrating the retrieved profiles with the air-mass profile within $15 \mathrm{~km}$ of the retrievals as follows:

$\mathrm{PC}_{\text {trop }}=\int_{0}^{15} X_{\mathrm{r}} \times A_{\mathrm{m}}$,

where $X_{\mathrm{r}}$ is the retrieved profile of $\mathrm{HCHO}, A_{\mathrm{m}}$ is the airmass profile, and $\mathrm{PC}_{\text {trop }}$ is the tropospheric $\mathrm{HCHO}$ column. The FTS total systematic error of the $\mathrm{HCHO}$ retrieval is less than $3.3 \%$, and the total random error is less than $9.6 \%$ (Sun et al., 2018). Due to the high accuracy, the trace gas concentrations measured using FTS have been widely used to validate corresponding satellite products (Yamamori et al., 2006; Jones et al., 2009; Yurganov et al., 2010; Reuter et al., 2011). Here we used the FTS HCHO measurement to validate the OMPS HCHO product.

\subsection{The China National Environmental Monitoring Center (CNEMC) network}

Surface air pollutants monitored on an hourly basis by CNEMC were provided by the Ministry of Environment Protection of the People's Republic of China (http://106.37.208. 233:20035/, last access: 8 May 2019). The national air quality monitoring network consisted of about 950 sites in 2013, and had extended to 1597 sites in 454 major cities by 2017 . Three trace gases, including $\mathrm{CO}, \mathrm{O}_{3}$, and $\mathrm{SO}_{2}$, inhalable particles $\left(\mathrm{PM}_{10}\right)$, and fine particulate matter $\left(\mathrm{PM}_{2.5}\right)$ are simultaneously measured by all sites, and the data have been widely used in various research (W.-N. Wang et al., 2017; Li et al., 2018; Liu et al., 2018; X. Lu et al., 2018). In this study, CO and $\mathrm{O}_{3}$ data from 2104 to 2017 were used. Data quality con- trols similar to those in previous studies (Barrero et al., 2015; He et al., 2017; Li et al., 2018) were applied to remove data outliers. Briefly, all hourly data at a specific monitoring site were transformed into $z$ scores, and then the transformed data $\left(Z_{i}\right)$ were removed if they met one of the following conditions: (1) the absolute $Z_{i}$ was larger than $4\left(\left|Z_{i}\right|>4\right)$, (2) the increment of $Z_{i}$ from the previous hourly value was larger than $9\left(\left|Z_{i}-Z_{i-1}\right|>9\right)$, or (3) the ratio of the $z$ score to its centered moving average of order 3 (MA3) was larger than 2 $\left(\frac{3 Z_{i}}{Z_{i-1}+Z_{i}+Z_{i+1}}>2\right)$.

\section{Results}

\subsection{Comparison with FTS tropospheric HCHO}

In order to validate the OMPS observations using FTS measurements, the HCHO tropospheric column measured using FTS was averaged around the OMPS satellite overpass time. The OMPS tropospheric HCHO column was selected for satellite pixels within $50 \mathrm{~km}$ of the Hefei site and with cloud fraction less than $20 \%$, and these pixels were averaged to minimize the random noise (Y. Wang et al., 2017). Figure 1a shows that tropospheric HCHO VCDs observed by OMPS and FTS are in good agreement $(R=0.78)$. The coincident time series of both data indicate that OMPS HCHO observations successfully capture the maximum $\mathrm{HCHO}$ concentration in summer and the minimum $\mathrm{HCHO}$ concentration in winter (Fig. 1b). However, it is important to note that the OMPS HCHO observations underestimate the tropospheric $\mathrm{HCHO}$ column by $0 \%-60 \%$ compared with the FTS results, especially in summer; these results are consistent with a previous study by De Smedt et al. (2015). The underestimation from OMPS was attributed to the spatial average from satellite observations, errors from HCHO SCDs affected by spectral fitting, and AMF calculation error which were affected by scattering weights calculated by the radiative transfer model and $\mathrm{HCHO}$ vertical profiles modeled by WRF-Chem (Zhu et al., 2016).

Most of the atmosphere $\mathrm{HCHO}$ was concentrated in the troposphere. The monthly averaged vertical profiles of HCHO shown in Fig. 2a indicate that the structure of the $\mathrm{HCHO}$ vertical profiles in different months was consistent. The HCHO concentration decreased by $70 \%$ with an increase in the height from 0.7 to $2 \mathrm{~km}$ and continued to decrease slowly in the troposphere above $2 \mathrm{~km}$. The ratio of the HCHO column below $1 \mathrm{~km}$ in the tropospheric $\mathrm{HCHO}$ column remained at $\sim 67 \%$ and did not show seasonal variation (Fig. 2b). The HCHO column below $1 \mathrm{~km}$ measured by FTS and the OMPS tropospheric HCHO column also showed good agreement ( $R=0.78$, Fig. S1 in the Supplement). The slope of 0.83 for the linear regression analysis between the FTS HCHO column below $1 \mathrm{~km}$ and the OMPS tropospheric column was higher than the slope of 0.51 for the regression between OMPS data and the tropospheric HCHO VCD 

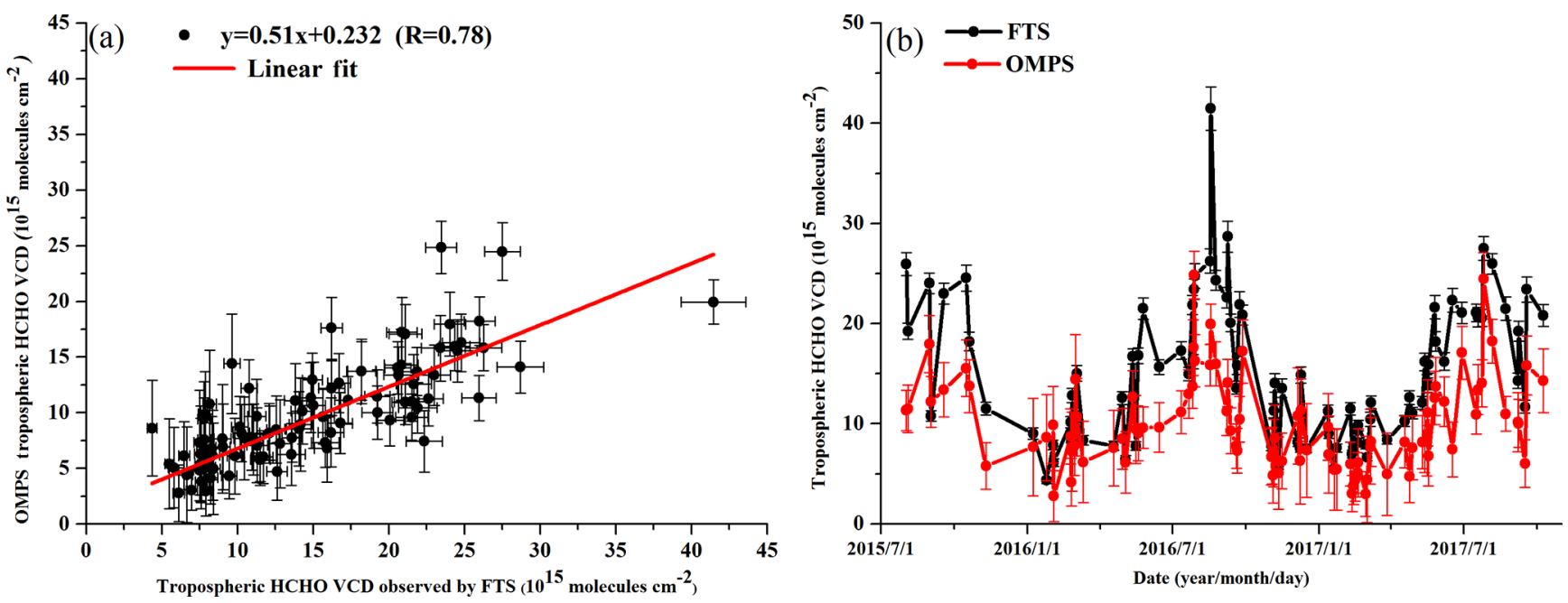

Figure 1. Correlation analysis (a) and time series (b) of tropospheric HCHO VCDs measured by OMPS and FTS from 1 July 2015 to 20 November 2017.
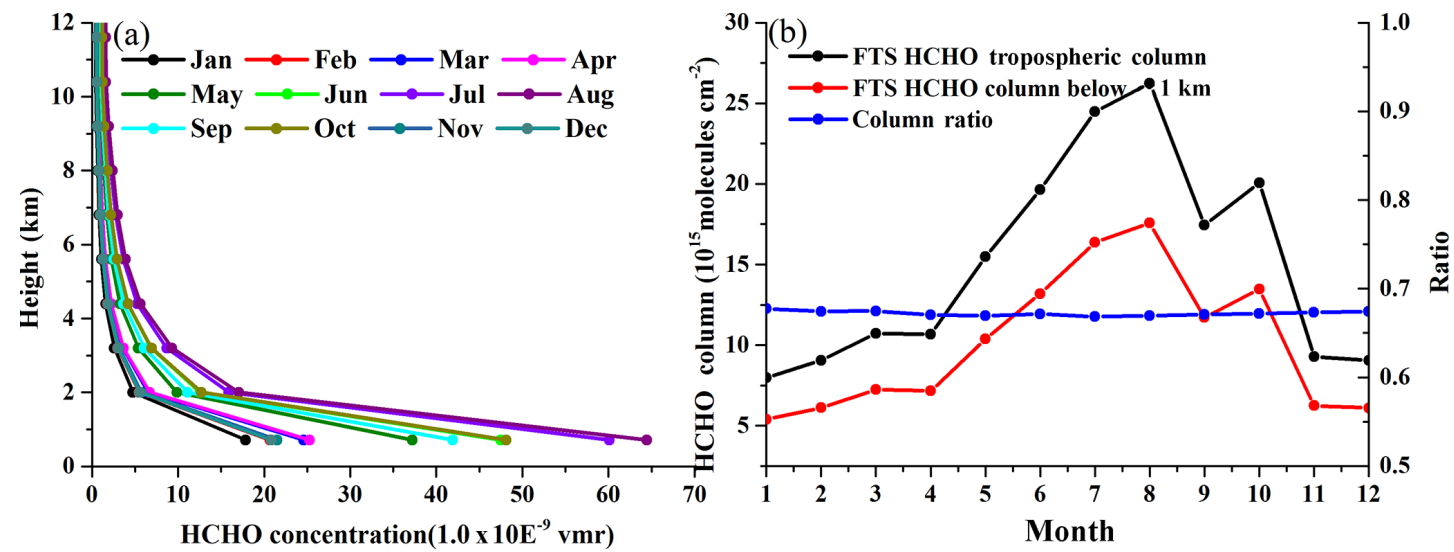

Figure 2. (a) The monthly averaged HCHO vertical profiles in the troposphere measured by FTS. (b) The monthly averaged tropospheric $\mathrm{HCHO}$ column (black line), the HCHO column below $1 \mathrm{~km}$ (red line) measured by FTS, and the ratio of the HCHO column below $1 \mathrm{~km}$ in the tropospheric $\mathrm{HCHO}$ column (blue line).

from FTS, indicating that the OMPS tropospheric $\mathrm{HCHO}$ column better represents the $\mathrm{HCHO}$ column below $1 \mathrm{~km}$. Furthermore, the mean of the relative differences between the HCHO column below $1 \mathrm{~km}$ measured by FTS and the tropospheric HCHO column measured by OMPS is zero. In previous studies, a uniform and constant correction factor has been applied to account for the bias between the tropospheric $\mathrm{HCHO}$ column observed by satellite and that measured by aircraft (e.g., Anderson et al., 2016). In this study, we regard the tropospheric HCHO column observed by OMPS as that below $1 \mathrm{~km}$ measured by FTS in terms of their numerical value. Assuming that $\mathrm{HCHO}$ mixes well within the $1 \mathrm{~km}$ above the surface, the mixing ratio of $\mathrm{HCHO}$ can be calculated as follows:

$M(\mathrm{ppbv})=\frac{1.25 \times \mathrm{VCD}\left(\text { molecules } \mathrm{cm}^{-2}\right)}{B \times \Delta p(\mathrm{~atm})}$, where $M$ is the mixing ratio of $\mathrm{HCHO}, B$ is unit conversion factor of DU to molecules $\mathrm{cm}^{-2}$ which is $2.688 \times 10^{16}$, VCD is the OMPS tropospheric HCHO VCDs, and $\Delta p$ is the pressure difference between the surface and $1 \mathrm{~km}$ (Ziemke et al., 2001; Lee et al., 2008).

\subsection{Spatiotemporal distribution of HCHO VCDs in the Yangtze River Delta}

The average HCHO VCD over China in August 2017 was $6.50 \times 10^{15}$ molecules $\mathrm{cm}^{-2}$, which would lead up to 50 people in every million to develop cancer. The total national cancer risk was estimated by combining the averaged $\mathrm{HCHO}$ VCDs with the population, and it was estimated that at least 33500 people in China would develop lung and nasopharyngeal cancer in their lifetime due to outdoor $\mathrm{HCHO}$ exposure using Eq. (4): 


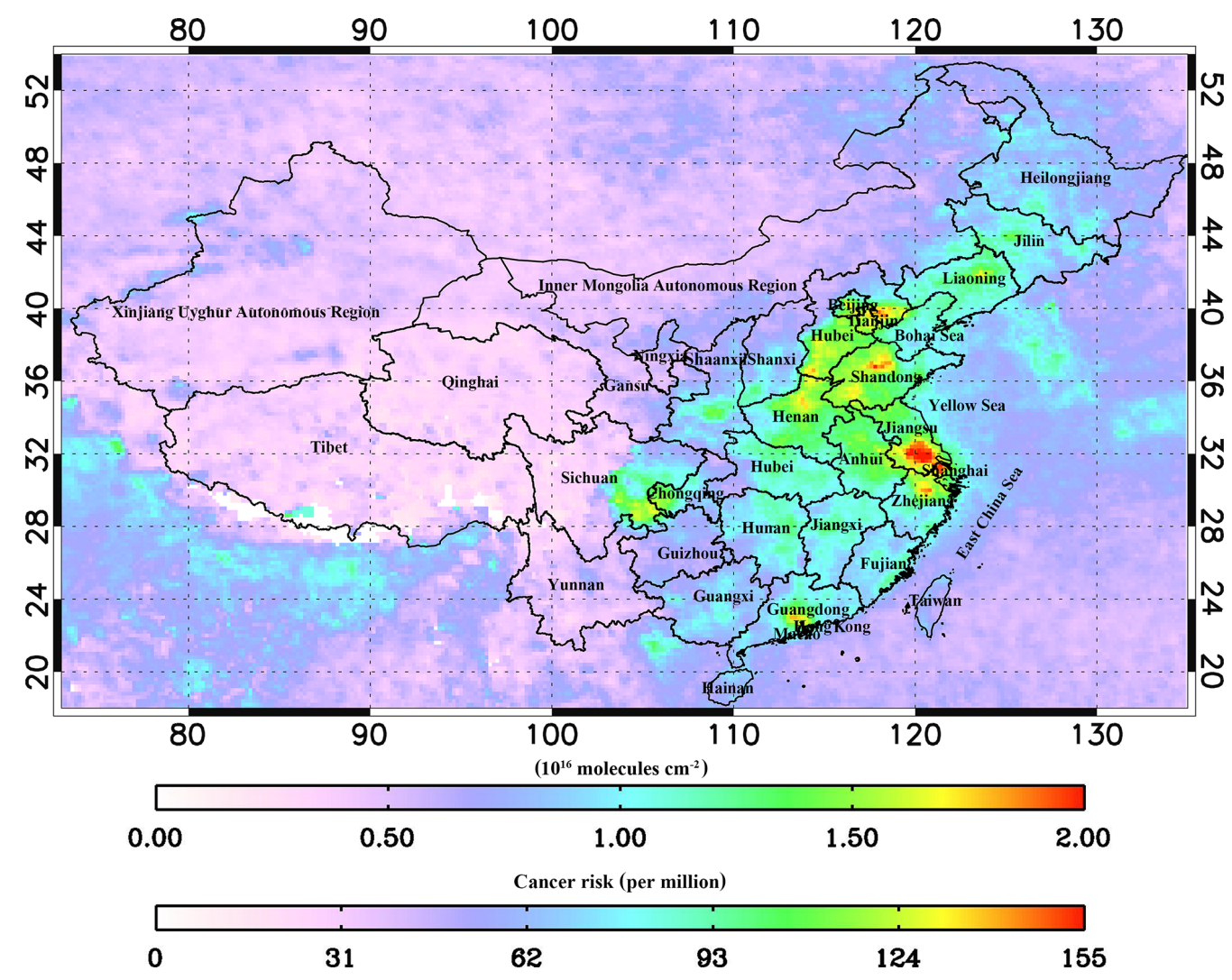

Figure 3. The spatial distribution of monthly averaged tropospheric HCHO VCDs observed by OMPS and the cancer risk in August 2017.

$T=\sum_{i} P_{i} \times C_{i}$

$Y=\frac{T}{L}$,

where $T$ is the total number of people in China who may develop cancer due to outdoor $\mathrm{HCHO}$ exposure, $P_{i}$ and $C_{i}$ represent the respective population and average cancer risk of provincial level administrative region $i, Y$ is the number of cancer cases per year, and $L$ is the life expectancy. Considering the life expectancy of 76.4 years (2015) in China (http://data.stats.gov.cn/easyquery.htm?cn= $\mathrm{C} 01 \& z b=\mathrm{A} 0304 \& \mathrm{sj}=2016$, last access: 8 May 2019, in Chinese), 439 cancer cases per year in China are caused by high outdoor HCHO concentrations (Eq. 5). The HCHO VCDs in most of western China, e.g., Yunnan Province, Tibet, Gansu Province, Qinghai Province, the Xinjiang Uyghur Autonomous Region, Ningxia Province, and the Inner Mongolia Autonomous Region, were lower than the national average (Fig. 3). The HCHO VCDs in central China were higher than the national average, and the distribution of HCHO VCDs was homogenous. The highest HCHO VCDs occurred in eastern China, specifically in the Beijing-Tianjin-Hebei region, the northern Henan Province, the western Shandong Province, the YRD region, and the Pearl River Delta (PRD) region, with the most severe $\mathrm{HCHO}$ pollution occurring in the YRD. The high outdoor HCHO concentration in the YRD increases the cancer risk for inhabitants, with up to 155 people in every million suffering cancer, which is about four times the cancer risk reported in the US (Zhu et al., 2017a). The total cancer risk in the YRD comprises $23.4 \%$ of total national cancer risk in China, and about 7840 people in the YRD may develop cancer during their lifetime due to severe HCHO pollution. Therefore, effectively controlling the ambient $\mathrm{HCHO}$ concentration in the YRD is an urgent issue. In addition, the YRD has been identified as the region with the highest emissions of VOCs (Qiu et al., 2014; Wu et al., 2015); therefore, the determination of the contribution from primary sources and secondary formation to ambient $\mathrm{HCHO}$ is needed to formulate appropriate control measures.

In the YRD region, the highest HCHO VCDs occurred in southwestern Jiangsu Province (e.g., Nanjing, Changzhou, Wuxi, and Suzhou cities), northern Zhejiang Province (e.g., Hangzhou, Jiaxing, Huzhou, and Ningbo cities), and Shanghai in 2015 (Fig. 4a). The spatial distribution of annual mean HCHO VCDs in 2016 and 2017 was similar to that in 2015. The HCHO VCDs in the YRD region showed a fluctuating trend from 2015 to 2017 (Fig. 4b, c). The HCHO concentration in Jiangsu Province rose from 2015 to 2016, whereas only HCHO VCDs in southwestern Jiangsu Province showed 


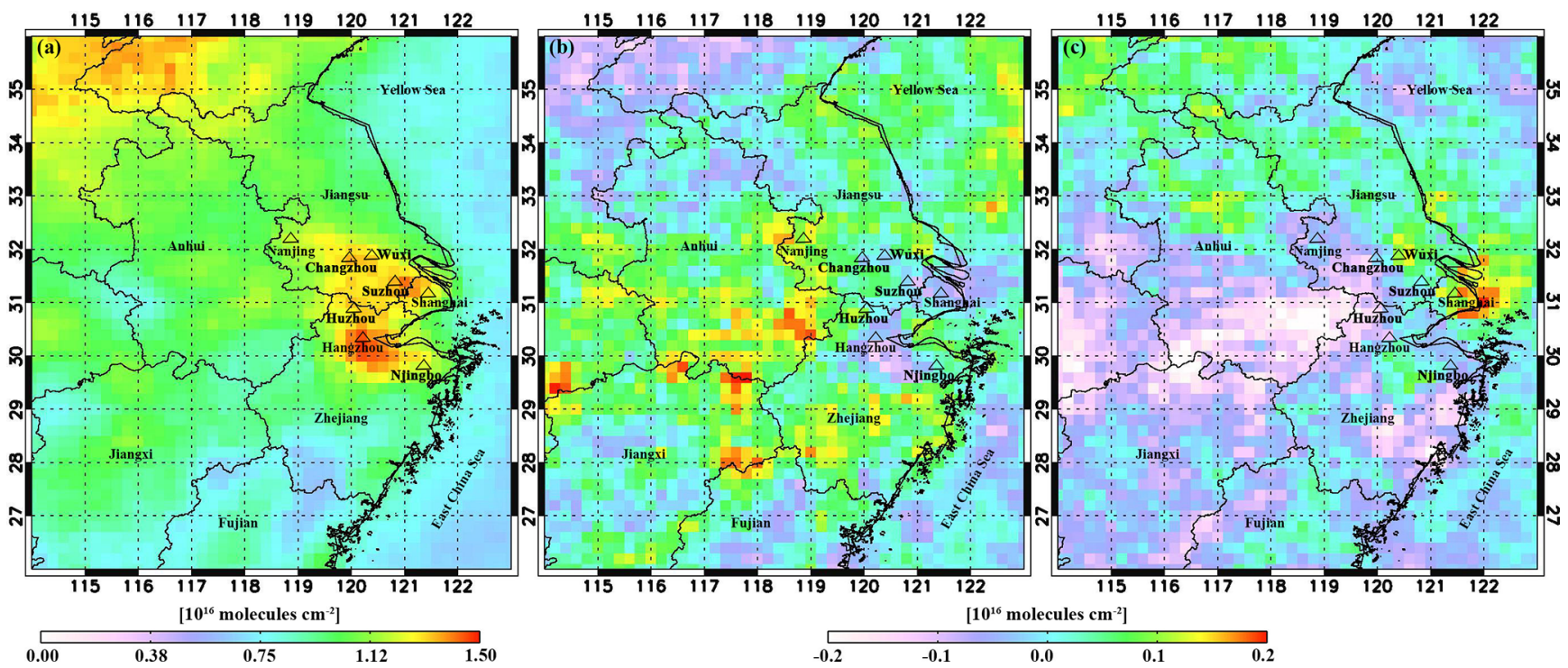

Figure 4. (a) The spatial distribution of annual mean tropospheric HCHO column observed by OMPS in the YRD in 2015, and (b) changes in the HCHO VCDs between 2016 and 2015 and (c) between 2017 and 2016.

a decreasing trend from 2016 to 2017 . The HCHO concentration in Shanghai and Hangzhou showed a similar trend: they clearly decreased from 2015 to 2016 and then increased from 2016 to 2017. An opposite trend was observed for HCHO VCDs in other cities in Zhejiang Province.

\subsection{Determination of primary and secondary contributions to ambient $\mathrm{HCHO}$}

The statistical analysis of simultaneous real-time measurements of $\mathrm{HCHO}, \mathrm{CO}$, and $\mathrm{O}_{3}$ can be described using a multiple regression model:

$$
\left[C_{\mathrm{HCHO}}\right]=\beta_{0}+\beta_{1} \times\left[C_{\mathrm{CO}}\right]+\beta_{2} \times\left[C_{\mathrm{O}_{3}}\right],
$$

where $\beta_{0}, \beta_{1}$, and $\beta_{2}$ are the coefficients fitted by the model (Garcia et al., 2006), and $\left[C_{\mathrm{HCHO}}\right],\left[C_{\mathrm{CO}}\right]$, and $\left[C_{\mathrm{O}_{3}}\right]$ represent the concentrations or the transformations of concentrations for $\mathrm{HCHO}, \mathrm{CO}$, and $\mathrm{O}_{3}$, respectively. Similar to Garcia et al. (2006), we applied 10 different transformations on the time series of $\mathrm{HCHO}, \mathrm{CO}$, and $\mathrm{O}_{3}$ : linear (no transformation), natural log, square root, second power, third power, inverse, inverse of natural log, inverse of square root, inverse of second power, and inverse of third power. Linear regression without transformation was identified as the best model (Table S1). The relative contributions of background concentration, primary emissions, and secondary formation to the ambient $\mathrm{HCHO}$ can be calculated using the following equations:

$$
\begin{aligned}
& R_{\text {Primary }}=\frac{\beta_{1} \times\left[C_{\mathrm{CO}}\right]}{\beta_{0}+\beta_{1} \times\left[C_{\mathrm{CO}}\right]+\beta_{2} \times\left[C_{\mathrm{O}_{3}}\right]} \times 100 \% \\
& R_{\text {Secondary }}=\frac{\beta_{2} \times\left[C_{\mathrm{O}_{3}}\right]}{\beta_{0}+\beta_{1} \times\left[C_{\mathrm{CO}}\right]+\beta_{2} \times\left[C_{\mathrm{O}_{3}}\right]} \times 100 \%
\end{aligned}
$$

$R_{\text {Background }}=\frac{\beta_{0}}{\beta_{0}+\beta_{1} \times\left[C_{\mathrm{CO}}\right]+\beta_{2} \times\left[C_{\mathrm{O}_{3}}\right]} \times 100 \%$,

where $R_{\text {Primary }}$ represents the contribution to ambient $\mathrm{HCHO}$ from primary sources (e.g., industrial and vehicle emissions), $R_{\text {Secondary }}$ represents the contribution to ambient $\mathrm{HCHO}$ from secondary sources (i.e., photochemical VOC oxidation), and $R_{\text {Background }}$ represents background contributions to the ambient $\mathrm{HCHO}$ which can not be classified as primary or secondary contributions. In previous studies in the YRD (Wang et al., 2015; Ma et al., 2016), the background HCHO concentration of $1 \mathrm{ppbv}$ has been selected to represent the $\mathrm{HCHO}$ concentration under regional conditions. Therefore, the $\beta_{0}$ coefficient is fixed at $1 \mathrm{ppbv}$ in the multiple linear regression in this study.

In a previous study, Ma et al. (2016) analyzed the primary emissions and secondary formation of HCHO from 15 April to 1 May 2015 at an industrial zone in Nanjing, which is located less than $15 \mathrm{~km}$ from one of our research site, Maigaoqiao (MGQ) station, using the in situ measurement of primary tracers (i.e., benzene, toluene, and $\mathrm{CO}$ ) and a secondary tracer (i.e., $\mathrm{O}_{3}$ ). Ma et al. (2016) found that the average relative contributions of industry-related emissions, secondary formation, and background were $59.2 \%, 13.8 \%$, and $27 \%$, respectively. In this study, the average relative contributions from primary sources, secondary formation, and background to $\mathrm{HCHO}$ at MGQ station during the same period were $50.5 \%, 30.8 \%$, and $18.7 \%$, respectively. We note that the relative contribution from primary emissions was similar to that reported by in Ma et al. (2016), with a difference of $8.7 \%$. However, the relative contribution from secondary formation was $17 \%$ larger and the relative contribution from background was $8.3 \%$ smaller than the values re- 
ported in Ma et al. (2016). It should be noted that the contribution of secondary formation we calculate is the maximum daily value, as the overpass time of the OMPS is 13:30 LT every day. Therefore, it is reasonable to assume that the contribution of secondary formation we calculate is also larger due to the favorable conditions for photochemical reactions at noon (Hong et al., 2018). In conclusion, the tropospheric HCHO column observed by OMPS can be used to analyze primary and secondary contributions to ambient $\mathrm{HCHO}$ via a multiple linear regression fit, and $\mathrm{CO}$ and $\mathrm{O}_{3}$ concentrations measured by CNEMC Network can be used as indicators of primary emission sources and secondary formation sources, respectively.

\subsubsection{Primary and secondary sources of ambient HCHO in Nanjing}

The distribution of the three stations selected to explore the primary and secondary sources of HCHO is shown in Fig. 5a, and the heavy industrial zones are delineated using red lines (Zheng et al., 2015). In order to ensure the representativeness of the regression model, only data fulfilling the criteria in the analysis (correlation coefficient $(R)$ larger than 0.6 and significance value lower than 0.05 ) were kept; the same data quality control was carried out for the Hangzhou and Shanghai analyses. We selected the MGQ site, located southwest of the industrial zones, the Ruijin Road site (RJR), located in the center of Nanjing, and the Xianlin University Town site (XLUT), located southeast the of industrial zones, to analyze the HCHO concentration from different sources in Nanjing. As presented in Table 1, the annual average HCHO concentrations at industrial sites were larger than those at an urban site in 2015 and 2017. The seasonal average HCHO concentration adheres to the following seasonal order in both the industrial zones and center of Nanjing (Fig. 6 and Table 3): summer $>$ autumn $>$ spring $>$ winter.

On average, secondary formation was the dominant source of ambient HCHO at all the three sites in Nanjing (Table 1). However, primary emission was found to be the most significant source in winter at the RJR site (Fig. 6a, b), in winter of 2015 at the MGQ site (Fig. 6c, d), and from August to December in 2015 at the XLUT site (Fig. 6e, f). At the industrial sites, MGQ and XLUT, the annual average HCHO concentration from primary emissions decreased by $64 \%$ and $63.44 \%$ from 2015 to 2017 in comparison with 2015, respectively. As coal combustion is an important primary source of ambient HCHO (Wang et al., 2013; Liu et al., 2017), energy saving methods and the reduction of energy consumption, especially the reduction of coal consumption, caused the decrease of primary $\mathrm{HCHO}$ emission, according to the Nanjing municipal government (http://www.nanjing.gov.cn/xxgk/szf/ 201403/t20140321_2544036.html, last access: 15 August 2018, in Chinese). The variation of the HCHO concentration from different sources at MGQ was similar to that at XLUT due to the short distance between the two sites. How-

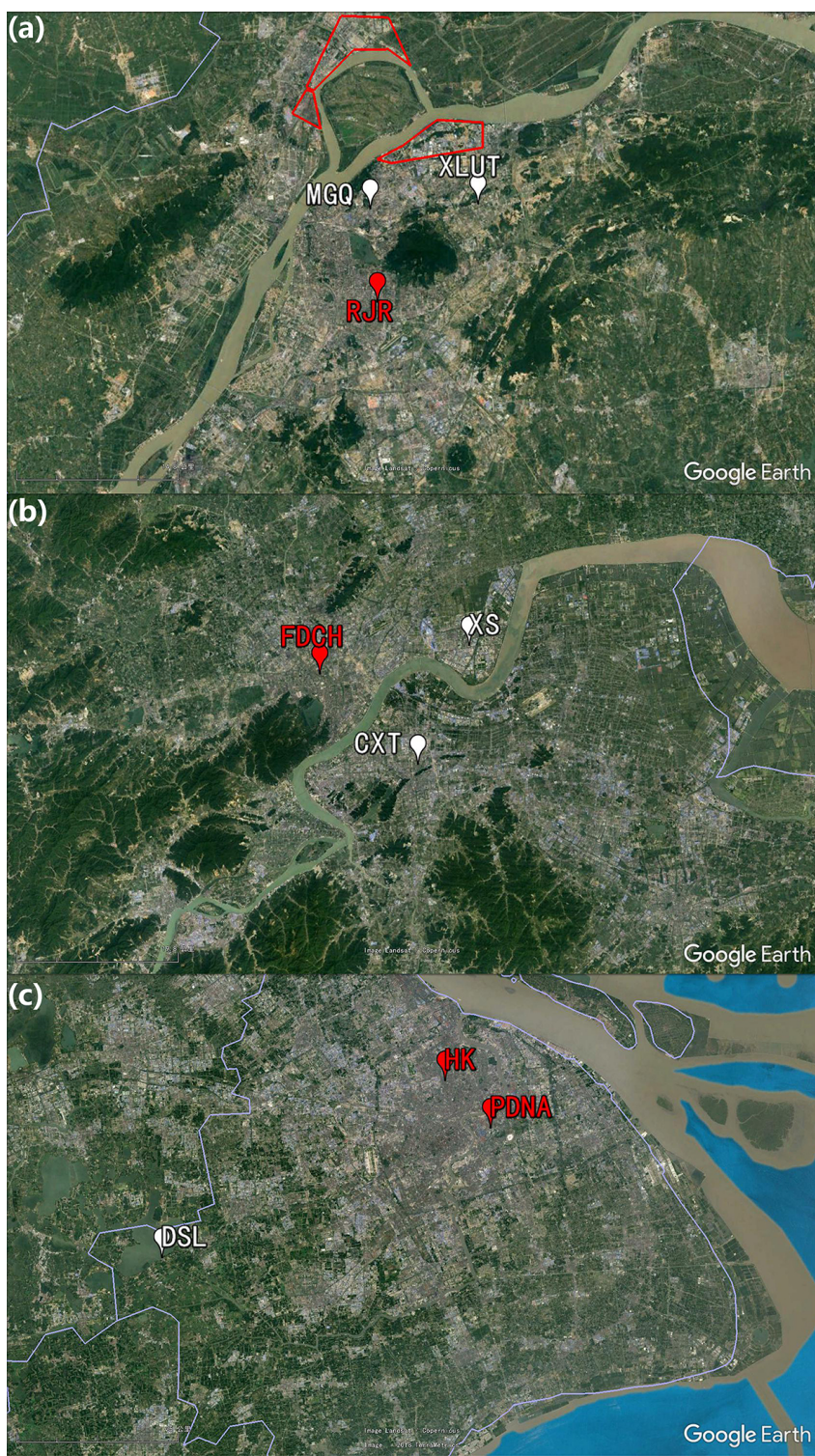

Figure 5. Maps of Nanjing (a), Hangzhou (b), and Shanghai (c). The suburban sites are marked using white, the downtown sites are marked using red, and the industrial zones are denoted using red lines.

ever, the annual average $\mathrm{HCHO}$ concentration from primary emissions at XLUT was larger than that at MGQ. Primary emissions of $\mathrm{HCHO}$ at the urban site were smaller than those at industrial sites in 2015 and larger than those at suburban sites in 2016 and 2017. The correlation coefficients between primary $\mathrm{HCHO}$ and total $\mathrm{HCHO}$ or secondary $\mathrm{HCHO}$ and total $\mathrm{HCHO}$ can be used to compare the contribution from the two sources to the variation of HCHO: a larger correlation coefficient means a higher contribution to the variation of HCHO. At the urban site, secondary formation contributed more to the variation of $\mathrm{HCHO}$ concentration from 2015 to $2017(R=0.76$, Fig. 7a) than primary emission $(R=0.35$, 

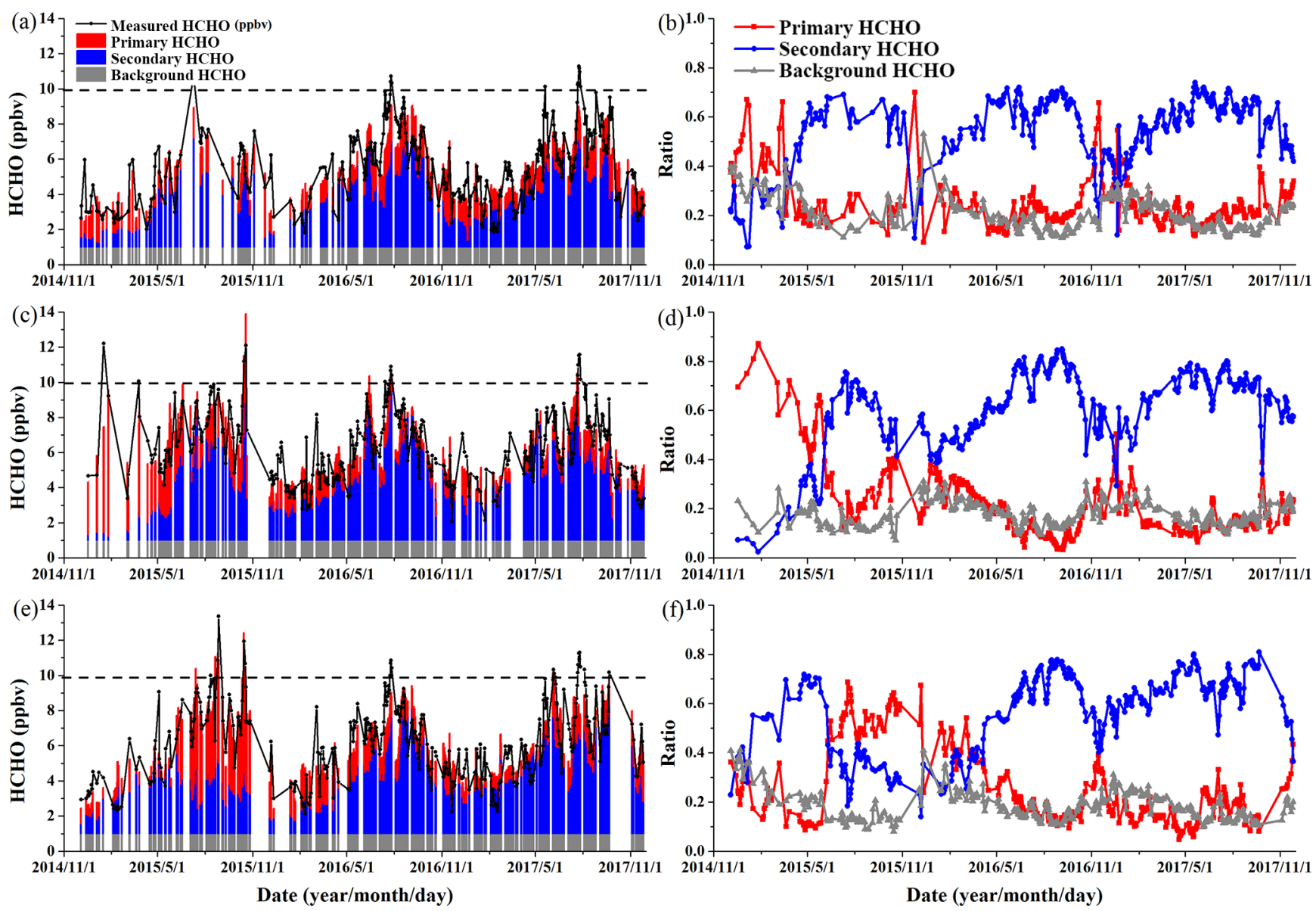

Figure 6. The time series of absolute $(\mathbf{a}, \mathbf{c}, \mathbf{e})$ and relative $(\mathbf{b}, \mathbf{d}, \mathbf{f})$ contributions of primary sources, secondary sources, and background sources to the HCHO concentration from December 2014 to November 2017 at the RJR site (a, b), the MGQ site (c, d), and the XLUT site (e,f) in Nanjing. Black dashed lines represent the threshold value for $\mathrm{HCHO}$ pollution.

Fig. S2a). While at the industrial sites, the contribution from secondary formation to the variation of the HCHO concentration was less evident $(R \leq 0.67$, Fig. $7 \mathrm{~b}, \mathrm{c})$. At the XLUT site, primary $\mathrm{HCHO}$ emission was more significant to the variation of the $\mathrm{HCHO}$ concentration than secondary formation in 2015 (Table 2). With respect to the seasonal average, secondary formation contributed most to the ambient $\mathrm{HCHO}$ concentration, and reached a maximum in summer, due to the improvement of photochemical reaction (Wang et al., 2016), and a minimum in winter (Table 3 ). In spring, summer, and autumn, the variation of the ambient $\mathrm{HCHO}$ was affected more by secondary formation, whereas in winter, it was influenced more by primary emission in the urban region (Table 4).

\subsubsection{Primary and secondary sources of ambient $\mathrm{HCHO}$ in Hangzhou}

Three sites, including Xiasha (XS), Chengxiang Town (CXT), and the "Fifth District of Chaohui" (FDCH) which are located in the northeastern suburbs, the eastern suburbs, and the center of Hangzhou, respectively, were selected to explore the sources of HCHO in Hangzhou, as shown in Fig. 5b. There was no significant difference between the HCHO concentrations at the suburban sites (Table 1). The $\mathrm{HCHO}$ concentration at these three sites reached a maximum in summer and a minimum in winter, which was in agreement with a previous study by De Smedt et al. (2015). The average $\mathrm{HCHO}$ concentration in 2016 was larger than the average concentrations in 2015 and 2017 at all three sites.

As shown in Table 1, secondary formation, with respect to the annual average, contributed more to ambient HCHO than primary emissions from 2015 to 2017 in Hangzhou. It is interesting that primary emissions of $\mathrm{HCHO}$ showed a small increasing trend from 2015 to 2017 at suburban sites (Fig. 8a, c, Table 1). According to the environment bulletin released by the Hangzhou government, this may have been caused by the significant increase in the number of vehicles and the less effective control measures regarding ambient $\mathrm{HCHO}$. Moreover, secondary $\mathrm{HCHO}$ also showed an important growing tendency from 2015 to 2016 and then began to decrease in 
Table 1. Annual average of the measured HCHO concentrations (ppbv) and absolute and relative contributions from different sources in Nanjing, Hangzhou, and Shanghai. The values in parentheses represent the contributions from different sources; lines 1-2 in each year refer to primary $\mathrm{HCHO}$, lines 3-4 refer to secondary $\mathrm{HCHO}$, and line 5 refers to measured $\mathrm{HCHO}$.

\begin{tabular}{|c|c|c|c|c|c|c|c|c|c|c|}
\hline \multirow[t]{2}{*}{ Year } & & \multicolumn{3}{|c|}{ Nanjing } & \multicolumn{3}{|c|}{ Hangzhou } & \multicolumn{3}{|c|}{ Shanghai } \\
\hline & & $\begin{array}{r}\text { MGQ } \\
\text { (industrial } \\
\text { zone) }\end{array}$ & $\begin{array}{r}\text { RJR } \\
\text { (urban } \\
\text { area) }\end{array}$ & $\begin{array}{r}\text { XLUT } \\
\text { (industrial } \\
\text { zone) }\end{array}$ & $\begin{array}{r}\mathrm{XS} \\
\text { (suburban) }\end{array}$ & $\begin{array}{r}\text { CXT } \\
\text { (suburban) }\end{array}$ & $\begin{array}{r}\text { FDCH } \\
\text { (urban } \\
\text { area) }\end{array}$ & $\begin{array}{r}\text { HK } \\
\text { (urban } \\
\text { area) }\end{array}$ & $\begin{array}{r}\text { PDNA } \\
\text { (urban } \\
\text { area) }\end{array}$ & $\begin{array}{r}\text { DSL } \\
\text { (suburban) }\end{array}$ \\
\hline \multirow[t]{3}{*}{2015} & Primary & $\begin{array}{r}2.528 \\
(36.86 \%)\end{array}$ & $\begin{array}{r}1.288 \\
(18.16 \%)\end{array}$ & $\begin{array}{r}2.853 \\
(14.63 \%)\end{array}$ & $\begin{array}{r}0.523 \\
(11.26 \%)\end{array}$ & $\begin{array}{r}0.333 \\
(8.76 \%)\end{array}$ & $\begin{array}{r}0.295 \\
(7.23 \%)\end{array}$ & $\begin{array}{r}1.956 \\
(31.08 \%)\end{array}$ & $\begin{array}{r}1.155 \\
(20.24 \%)\end{array}$ & $\begin{array}{r}2.602 \\
(37.15 \%)\end{array}$ \\
\hline & Secondary & $\begin{array}{r}3.556 \\
(48.13 \%)\end{array}$ & $\begin{array}{r}2.342 \\
(46.41 \%)\end{array}$ & $\begin{array}{r}2.601 \\
(42.80 \%)\end{array}$ & $\begin{array}{r}2.892 \\
(62.20 \%)\end{array}$ & $\begin{array}{r}3.258 \\
(65.40 \%)\end{array}$ & $\begin{array}{r}3.483 \\
(68.13 \%)\end{array}$ & $\begin{array}{r}3.497 \\
(52.66 \%)\end{array}$ & $\begin{array}{r}3.681 \\
(61.68 \%)\end{array}$ & $\begin{array}{r}2.535 \\
(43.71 \%)\end{array}$ \\
\hline & Measured & 7.205 & 4.68 & 6.506 & 4.434 & 4.656 & 4.817 & 6.422 & 5.822 & 6.145 \\
\hline \multirow[t]{3}{*}{2016} & Primary & $\begin{array}{r}0.933 \\
(17.75 \%)\end{array}$ & $\begin{array}{r}1.411 \\
(11.49 \%)\end{array}$ & $\begin{array}{r}1.328 \\
(23.87 \%)\end{array}$ & $\begin{array}{r}1.154 \\
(27.57 \%)\end{array}$ & $\begin{array}{r}0.768 \\
(14.55 \%)\end{array}$ & $\begin{array}{r}1.981 \\
(37.22 \%)\end{array}$ & $\begin{array}{r}0.792 \\
(13.08 \%)\end{array}$ & $\begin{array}{r}2.348 \\
(42.52 \%)\end{array}$ & $\begin{array}{r}1.015 \\
(17.10 \%)\end{array}$ \\
\hline & Secondary & 3.948 & 3.804 & $\begin{array}{r}3.776 \\
5858\end{array}$ & $\begin{array}{r}3.053 \\
(5084 \%\end{array}$ & 4.033 & $\begin{array}{r}2.418 \\
560\end{array}$ & $\begin{array}{r}4.275 \\
(6851 \%\end{array}$ & 3.688 & $\begin{array}{r}4.309 \\
(65.40 \%)\end{array}$ \\
\hline & Measured & 5.945 & 6.249 & 6.14 & 5.137 & 5.356 & 5.294 & 6.08 & 5.972 & 6.324 \\
\hline \multirow[t]{3}{*}{2017} & Primary & $\begin{array}{r}0.910 \\
(15.39 \%)\end{array}$ & $\begin{array}{r}1.209 \\
(10.19 \%)\end{array}$ & $\begin{array}{r}1.043 \\
(16.48 \%)\end{array}$ & $\begin{array}{r}2.233 \\
(25.84 \%)\end{array}$ & $\begin{array}{r}0.687 \\
(14.53 \%)\end{array}$ & $\begin{array}{r}0.511 \\
(12.03 \%)\end{array}$ & $\begin{array}{r}0.816 \\
(13.19 \%)\end{array}$ & $\begin{array}{r}1.408 \\
(25.72 \%)\end{array}$ & $\begin{array}{r}0.945 \\
(15.21 \%)\end{array}$ \\
\hline & Secondary & $\begin{array}{r}4.264 \\
(67.50 \%)\end{array}$ & $\begin{array}{r}3.303 \\
(57.76 \%)\end{array}$ & $\begin{array}{r}4.209 \\
(66.18 \%)\end{array}$ & $\begin{array}{r}1.823 \\
(50.66 \%)\end{array}$ & $\begin{array}{r}3.276 \\
(62.36 \%)\end{array}$ & $\begin{array}{r}3.112 \\
(62.74 \%)\end{array}$ & $\begin{array}{r}4.823 \\
(70.14 \%)\end{array}$ & $\begin{array}{r}3.591 \\
(56.16 \%)\end{array}$ & $\begin{array}{r}4.259 \\
(66.55 \%)\end{array}$ \\
\hline & Measured & 6.205 & 5.461 & 6.289 & 5.022 & 4.926 & 4.626 & 6.609 & 5.916 & 6.181 \\
\hline
\end{tabular}

Table 2. The Pearson correlation coefficient $(R)$ between the measured HCHO and primary HCHO emissions and secondary HCHO formation in Nanjing, Hangzhou, and Shanghai from 2015 to 2017. Line 1 in each year refers to primary HCHO and line 2 refers to secondary $\mathrm{HCHO}$.

\begin{tabular}{llrrr|rrr|rrr}
\hline Year & \multicolumn{3}{c}{ Nanjing } & \multicolumn{2}{c}{ Hangzhou } & \multicolumn{2}{c}{ Shanghai } \\
\cline { 3 - 10 } & & $\begin{array}{r}\text { MGQ } \\
\text { (industrial } \\
\text { zone) }\end{array}$ & $\begin{array}{r}\text { RJR } \\
\text { (urban } \\
\text { area) }\end{array}$ & $\begin{array}{r}\text { XLUT } \\
\text { (industrial } \\
\text { zone) }\end{array}$ & $\begin{array}{r}\text { XS } \\
\text { (suburban) }\end{array}$ & $\begin{array}{r}\text { CXT } \\
\text { (suburban) }\end{array}$ & $\begin{array}{r}\text { FDCH } \\
\text { (urban } \\
\text { area) }\end{array}$ & $\begin{array}{r}\text { HK } \\
\text { (urban } \\
\text { area) }\end{array}$ & $\begin{array}{r}\text { PDNA } \\
\text { (urban } \\
\text { area) }\end{array}$ & $\begin{array}{r}\text { DSL } \\
\text { (suburban) }\end{array}$ \\
\hline \multirow{2}{*}{2015} & Primary & 0.14 & 0.21 & 0.84 & 0.69 & -0.1 & 0.06 & 0.18 & 0.2 & 0.83 \\
& Secondary & 0.58 & 0.75 & 0.47 & 0.9 & 0.82 & 0.81 & 0.55 & 0.65 & 0.61 \\
\hline \multirow{2}{*}{2016} & Primary & -0.43 & 0.27 & -0.3 & -0.4 & 0.31 & 0.51 & 0.42 & 0.06 & 0.28 \\
& Secondary & 0.82 & 0.71 & 0.73 & 0.77 & 0.84 & 0.68 & 0.77 & 0.69 & 0.81 \\
\hline \multirow{2}{*}{2017} & Primary & 0.07 & 0.5 & 0.51 & 0.84 & 0.42 & 0.38 & 0.26 & 0.06 \\
& Secondary & 0.7 & 0.77 & 0.74 & 0.68 & 0.76 & 0.79 & 0.77 & 0.75 & 0.58 \\
\hline
\end{tabular}

2017. The variation of the $\mathrm{HCHO}$ concentration was mainly affected by secondary formation from 2015 to 2017, due to the strong correlation $(R>0.7$; Fig. $7 \mathrm{~d}, \mathrm{e}, \mathrm{f})$. In all seasons, the seasonal average of secondary formation from 2015 to 2017 was larger than primary emissions in Hangzhou (Table 3 ). In contrast, primary emission were seen to exceed secondary formation and become the main source on individual days in winter of 2016 and in summer of 2017 at the XS site (Fig. 8a, b), in winter of 2016 at the CXT site (Fig. 8c, d), and in winter of 2016 and 2017 at urban site (Fig. 8e, f). In winter, the impact of primary emission on the variation of $\mathrm{HCHO}$ was more significant than secondary formation, whereas in spring, summer, and autumn, secondary formation became more important to the variation of ambient $\mathrm{HCHO}$, except in the northeastern suburbs in autumn (Table 4).

\subsubsection{Primary and secondary sources of ambient HCHO in Shanghai}

The "Pudong New Area" site (PDNA), the Hongkou site (HK), and the "Dianshan Lake in Qingpu" site (DSL) were selected to represent east of the city center, north of the city center, and the suburbs, respectively (Fig. 5c). The annual average $\mathrm{HCHO}$ concentration decreased by $0.342 \mathrm{ppbv}$ from 2015 to 2016 and increased by 0.529 ppbv from 2016 to 2017 at the HK site (Table 1). The annual average HCHO concentration at the PDNA site increased by 0.15 ppbv in 2016 and 

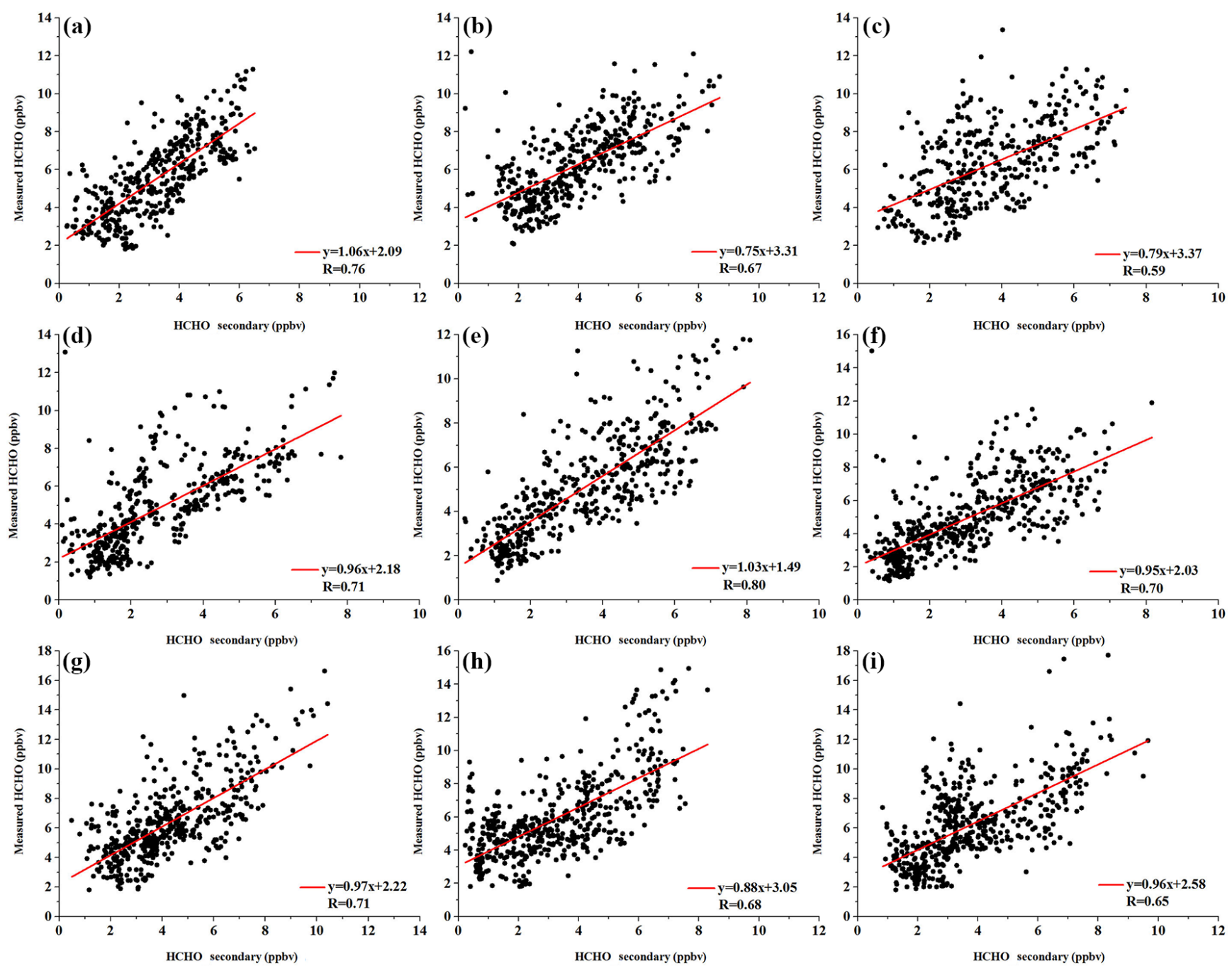

Figure 7. Correlation analysis of total HCHO and secondary HCHO from 2015 to 2017 at the RJR site (a), the MGQ site (b), and the XLUT site (c) in Nanjing; at the XS site (d), the CXT site (e), and the FDCH site (f) in Hangzhou; and at the HK site (g), the PDNA site (h), and the DSL site (i) in Shanghai (significance values are equal to zero).

decreased by $0.056 \mathrm{ppbv}$ in 2017, compared with that from the previous year. At the DSL site, the HCHO concentration was less than that at HK, except in 2016. The HCHO concentration at DSL initially increased by 0.179 ppbv from 2015 to 2016 and then decreased by 0.143 ppbv from 2016 to 2017. We can conclude that the ambient HCHO concentration has not been strictly controlled in recent years. With respect to the seasonal average, the HCHO concentration reached a maximum in summer and a minimum in winter in Shanghai, which concurs with findings from Nanjing and Hangzhou (Table 3). Moreover, the HCHO concentration in Shanghai in summer was larger than that in Nanjing and Hangzhou.

On average, secondary formation was the most significant contribution to ambient $\mathrm{HCHO}$ in Shanghai, except at the PDNA site in 2016 (Table 1 and Fig. 9). The contribution from secondary formation developed, showing a ris- ing trend, and primary $\mathrm{HCHO}$ emission showed a decreasing trend from 2015 to 2017, at the suburban site (Fig. 9e, $\mathrm{f}$, Table 1). The variation of the HCHO concentration was more strongly affected by secondary formation $(R>0.70$, Fig. $7 \mathrm{~g}, \mathrm{~h}, \mathrm{i})$ than primary emissions $(R<0.43$, Fig. $\mathrm{S} 2 \mathrm{~g}, \mathrm{~h}$, i) from 2015 to 2017. In summer and autumn, secondary formation was the largest source of ambient HCHO (Fig. 9a, $\mathrm{b}, \mathrm{c}, \mathrm{d})$ and was the main factor influencing the variation of the HCHO concentration in urban regions of Shanghai. At PDNA site, in comparison, primary emissions $(R=0.61$, Table 4) had a more significant influence on the variation of ambient HCHO than secondary formation $(R=-0.42$, Table 4) in winter, and it became the most important source of ambient HCHO in spring and winter of 2016. The secondary sources of $\mathrm{HCHO}$ in the three megacities showed a similar seasonal variation, and showed a similar order of influence 
Table 3. Seasonal average of the measured HCHO concentrations (ppbv) and absolute and relative contributions from different sources from 2015 to 2017 in Nanjing, Hangzhou, and Shanghai.The values in parentheses represent the contributions from different sources; lines 1-2 in each season refer to primary $\mathrm{HCHO}$, lines 3-4 refer to secondary $\mathrm{HCHO}$, and line 5 refers to measured $\mathrm{HCHO}$.

\begin{tabular}{|c|c|c|c|c|c|c|c|c|c|c|}
\hline \multirow[t]{2}{*}{ Season } & & \multicolumn{3}{|c|}{ Nanjing } & \multicolumn{3}{|c|}{ Hangzhou } & \multicolumn{3}{|c|}{ Shanghai } \\
\hline & & $\begin{array}{r}\text { MGQ } \\
\text { (industrial } \\
\text { zone) }\end{array}$ & $\begin{array}{r}\text { RJR } \\
\text { (urban } \\
\text { area) }\end{array}$ & $\begin{array}{r}\text { XLUT } \\
\text { (industrial } \\
\text { zone) }\end{array}$ & $\begin{array}{r}\text { XS } \\
\text { (suburban) }\end{array}$ & $\begin{array}{r}\text { CXT } \\
\text { (suburban) }\end{array}$ & $\begin{array}{r}\mathrm{FDCH} \\
\text { (urban } \\
\text { area) }\end{array}$ & $\begin{array}{r}\text { HK } \\
\text { (urban } \\
\text { area) }\end{array}$ & $\begin{array}{r}\text { PDNA } \\
\text { (urban } \\
\text { area) }\end{array}$ & $\begin{array}{r}\text { DSL } \\
\text { (suburban) }\end{array}$ \\
\hline \multirow[t]{5}{*}{ Winter } & Primary & 1.398 & 1.151 & 1.013 & 0.866 & 0.46 & 0.876 & 1.032 & 2.383 & 0.741 \\
\hline & & $(29.45 \%)$ & $(32.01 \%)$ & $(25.15 \%)$ & $(25.58 \%)$ & $(16.50 \%)$ & $(25.77 \%)$ & $(22.25 \%)$ & $(50.13 \%)$ & $(20.72 \%)$ \\
\hline & Secondary & 2.011 & 1.469 & 1.993 & 1.209 & 1.332 & 1.061 & 2.197 & 1.212 & 1.874 \\
\hline & & $(47.15 \%)$ & $(39.54 \%)$ & $(48.73 \%)$ & $(40.75 \%)$ & $(46.82 \%)$ & $(38.48 \%)$ & $(53.13 \%)$ & $(27.54 \%)$ & $(51.17 \%)$ \\
\hline & Measured & 4.403 & 3.394 & 3.694 & 2.627 & 2.342 & 2.491 & 3.841 & 4.098 & 3.338 \\
\hline \multirow[t]{5}{*}{ Spring } & Primary & 1.51 & 0.981 & 0.922 & 0.606 & 0.44 & 0.645 & 0.728 & 1.598 & 0.589 \\
\hline & & $(27.04 \%)$ & $(20.00 \%)$ & $(18.14 \%)$ & $(15.89 \%)$ & $(10.71 \%)$ & (16.59) & $(14.30 \%)$ & $(35.00 \%)$ & $(12.70 \%)$ \\
\hline & Secondary & 3.017 & 2.996 & 3.365 & 2.352 & 2.744 & 2.288 & 3.399 & 2.043 & 3.166 \\
\hline & & $(54.37 \%)$ & $(59.04 \%)$ & $(62.45 \%)$ & $(57.94 \%)$ & $(64.27 \%)$ & $(57.21 \%)$ & $(65.71 \%)$ & $(42.88 \%)$ & $(65.83 \%)$ \\
\hline & Measured & 5.619 & 5.161 & 5.575 & 4.259 & 4.473 & 4.193 & 5.334 & 4.946 & 4.975 \\
\hline \multirow[t]{5}{*}{ Summer } & Primary & 1.047 & 1.414 & 1.964 & 1.878 & 0.695 & 1.139 & 1.051 & 1.526 & 2.013 \\
\hline & & $(13.89 \%)$ & $(20.64 \%)$ & $(25.53 \%)$ & $(25.59 \%)$ & $(10.26 \%)$ & $(16.86 \%)$ & $(13.75 \%)$ & $(19.98 \%)$ & $(24.31 \%)$ \\
\hline & Secondary & 5.503 & 4.484 & 4.542 & 4.389 & 5.143 & 4.512 & 5.875 & 5.273 & 5.361 \\
\hline & & $(72.46 \%)$ & $(64.54 \%)$ & $(60.70 \%)$ & $(60.45 \%)$ & $(74.66 \%)$ & $(67.79 \%)$ & $(72.97 \%)$ & $(66.66 \%)$ & $(63.41 \%)$ \\
\hline & Measured & 7.764 & 7.277 & 7.919 & 7.451 & 7.189 & 6.936 & 8.36 & 8.196 & 8.602 \\
\hline \multirow[t]{5}{*}{ Autumn } & Primary & 1.103 & 1.537 & 1.99 & 1.485 & 0.775 & 0.982 & 1.538 & 1.529 & 2.231 \\
\hline & & $(18.36 \%)$ & $(26.40 \%)$ & $(28.31 \%)$ & $(20.11 \%)$ & $(14.86 \%)$ & $(17.48 \%)$ & $(23.46 \%)$ & $(22.93 \%)$ & $(30.91 \%)$ \\
\hline & Secondary & 3.905 & 3.462 & 3.921 & 4.478 & 4.163 & 3.876 & 4.241 & 4.163 & 3.87 \\
\hline & & $(63.95 \%)$ & $(55.73 \%)$ & $(56.39 \%)$ & $(64.87 \%)$ & $(66.62 \%)$ & $(64.08 \%)$ & $(61.15 \%)$ & $(61.65 \%)$ & $(54.57 \%)$ \\
\hline & Measured & 5.851 & 5.463 & 6.352 & 6.654 & 5.496 & 5.477 & 6.183 & 5.937 & 6.789 \\
\hline
\end{tabular}

Table 4. The Pearson correlation coefficient $(R)$ between the measured HCHO and primary HCHO emission and secondary HCHO formation in Nanjing, Hangzhou, and Shanghai in winter, spring, summer, and autumn. Line 1 in each season refers to primary HCHO and line 2 refers to secondary HCHO.

\begin{tabular}{|c|c|c|c|c|c|c|c|c|c|c|}
\hline \multirow[t]{2}{*}{ Season } & & \multicolumn{3}{|c|}{ Nanjing } & \multicolumn{3}{|c|}{ Hangzhou } & \multicolumn{3}{|c|}{ Shanghai } \\
\hline & & $\begin{array}{r}\text { MGQ } \\
\text { (industrial } \\
\text { zone) }\end{array}$ & $\begin{array}{r}\text { RJR } \\
\text { (urban } \\
\text { area) }\end{array}$ & $\begin{array}{r}\text { XLUT } \\
\text { (industrial } \\
\text { zone) }\end{array}$ & $\begin{array}{r}\text { XS } \\
\text { (suburban) }\end{array}$ & $\begin{array}{r}\text { CXT } \\
\text { (suburban) }\end{array}$ & $\begin{array}{c}\text { FDCH } \\
\text { (urban } \\
\text { area) }\end{array}$ & $\begin{array}{r}\text { HK } \\
\text { (urban } \\
\text { area) }\end{array}$ & $\begin{array}{r}\text { PDNA } \\
\text { (urban } \\
\text { area) }\end{array}$ & $\begin{array}{r}\text { DSL } \\
\text { (suburban) }\end{array}$ \\
\hline Winter & $\begin{array}{l}\text { Primary } \\
\text { Secondary }\end{array}$ & $\begin{array}{r}0.67 \\
-0.41\end{array}$ & $\begin{array}{r}0.24 \\
-0.23\end{array}$ & $\begin{array}{r}-0.05 \\
0.12 \\
\end{array}$ & $\begin{array}{r}0.42 \\
-0.24\end{array}$ & $\begin{array}{l}0.01 \\
0.03\end{array}$ & $\begin{array}{r}0.47 \\
-0.25\end{array}$ & $\begin{array}{r}0.61 \\
-0.42 \\
\end{array}$ & $\begin{array}{r}0.61 \\
-0.42\end{array}$ & $\begin{array}{r}0.5 \\
-0.44\end{array}$ \\
\hline Spring & $\begin{array}{l}\text { Primary } \\
\text { Secondary }\end{array}$ & $\begin{array}{l}0.11 \\
0.25 \\
\end{array}$ & $\begin{array}{r}0.21 \\
0.6 \\
\end{array}$ & $\begin{array}{l}0.17 \\
0.43\end{array}$ & $\begin{array}{l}0.04 \\
0.43\end{array}$ & $\begin{array}{l}0.29 \\
0.47\end{array}$ & $\begin{array}{l}0.13 \\
0.26\end{array}$ & $\begin{array}{l}0.12 \\
0.56\end{array}$ & $\begin{array}{l}0.16 \\
0.39\end{array}$ & $\begin{array}{r}-0.21 \\
0.62 \\
\end{array}$ \\
\hline Summer & $\begin{array}{l}\text { Primary } \\
\text { Secondary }\end{array}$ & $\begin{array}{l}0.17 \\
0.45\end{array}$ & $\begin{array}{l}0.54 \\
0.59\end{array}$ & $\begin{array}{l}0.22 \\
0.26\end{array}$ & $\begin{array}{l}0.08 \\
0.33\end{array}$ & $\begin{array}{r}-0.02 \\
0.69 \\
\end{array}$ & $\begin{array}{r}0.2 \\
0.35\end{array}$ & $\begin{array}{l}0.1 \\
0.6\end{array}$ & $\begin{array}{l}0.34 \\
0.62 \\
\end{array}$ & $\begin{array}{l}0.08 \\
0.35\end{array}$ \\
\hline Autumn & $\begin{array}{l}\text { Primary } \\
\text { Secondary }\end{array}$ & $\begin{array}{l}0.42 \\
0.71\end{array}$ & $\begin{array}{l}0.26 \\
0.68\end{array}$ & $\begin{array}{l}0.54 \\
0.37\end{array}$ & $\begin{array}{l}0.71 \\
0.12\end{array}$ & $\begin{array}{l}0.05 \\
0.48\end{array}$ & $\begin{array}{r}-0.03 \\
0.55\end{array}$ & $\begin{array}{l}0.26 \\
0.41\end{array}$ & $\begin{array}{l}0.36 \\
0.48\end{array}$ & $\begin{array}{l}0.31 \\
0.19\end{array}$ \\
\hline
\end{tabular}

to the seasonal variation of $\mathrm{HCHO}$ concentration: summer $>$ autumn $>$ spring $>$ winter. The HCHO concentration from secondary formation in Shanghai in summer was larger than that in Nanjing and Hangzhou.

\section{Discussion}

\subsection{Reconsidering the proxy for VOC reactivity using the HCHO concentration}

Duncan et al. (2010) determined the indicator of VOC and $\mathrm{NO}_{\mathrm{x}}$ controls on surface $\mathrm{O}_{3}$ formation using $\mathrm{HCHO}$ VCDs 

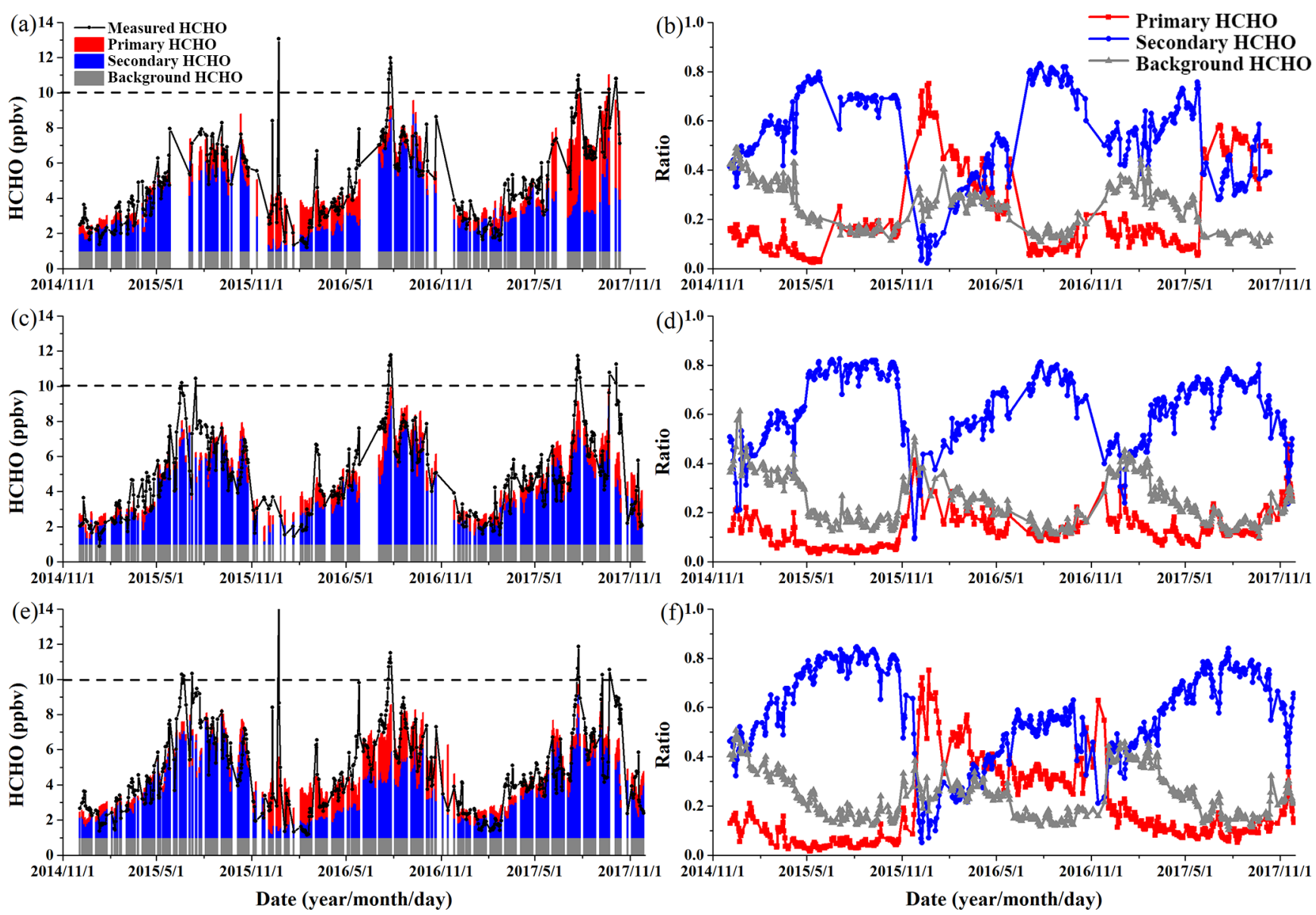

Figure 8. The time series of absolute $(\mathbf{a}, \mathbf{c}, \mathbf{e})$ and relative $(\mathbf{b}, \mathbf{d}, \mathbf{f})$ contributions of primary sources, secondary sources, and background sources to the HCHO concentration from December 2014 to November 2017 at the XS (a, b), CXT (c, d), and FDCH (e, f) sites in Hangzhou. Black dashed lines represent the threshold value for $\mathrm{HCHO}$ pollution.

observed by OMI as the proxy for VOC reactivity in August between 2005 and 2007 in the US. This is reasonable, as the ambient $\mathrm{HCHO}$ concentration mainly stemmed from the atmospheric oxidation of isoprene in summer over North America (Palmer et al., 2003; Zhu et al., 2017b; Marvin et al., 2017); furthermore, the HCHO concentration from secondary formation contributed $87 \%$ during daytime in Los Angeles in the 1980s (Kawamura et al., 2000), and over $80 \%$ of the ambient HCHO concentration is from secondary formation over the eastern US (Luecken et al., 2006). However, the contribution from secondary formation in the YRD is smaller than that in the US, accounting for about $70 \%$ in summer and $40 \%-54 \%$ in winter. The good correlation between total $\mathrm{HCHO}$ and secondary $\mathrm{HCHO}$ results in a good correlation between total $\mathrm{HCHO}$ and $\mathrm{RO}_{2}$, which means that total $\mathrm{HCHO}$ is an appropriate proxy for VOC reactivity in this case. Total HCHO can be regarded as the proxy for VOC reactivity over a 3-year study period from 2015 to 2017 due to the good correlation between total $\mathrm{HCHO}$ and secondary $\mathrm{HCHO}$ in Nanjing, Hangzhou, and Shanghai $(R \geq 0.59)$. If the study period was restricted to 2015 , using the ambient $\mathrm{HCHO}$ concentration to indicate VOC reactivity would cause significant errors, as ambient $\mathrm{HCHO}$ showed a stronger correlation with primary emission than secondary formation during this period (e.g., in the industrial zone of Nanjing and in the suburbs of Shanghai). In addition, the correlation between total $\mathrm{HCHO}$ and secondary $\mathrm{HCHO}$ depends on season. In winter, the ambient $\mathrm{HCHO}$ concentration cannot be represented by the concentration from secondary formation due to the poor correlation $(R<0.12, P>0.05)$. However, in spring (at RJR and DSL), in summer (at RJR, CXT, HK, and PDNA), and in autumn (at RJR and MGQ) total HCHO can be used as a proxy for VOC reactivity $(R>0.59, P<0.01)$.

\subsection{HCHO control measures adapted to local conditions}

Sources of ambient $\mathrm{HCHO}$ at different sites varied largely and were closely related to the types of industries present (Zheng et al., 2016). In order to better adapt HCHO control measures to local conditions, it is meaningful to esti- 

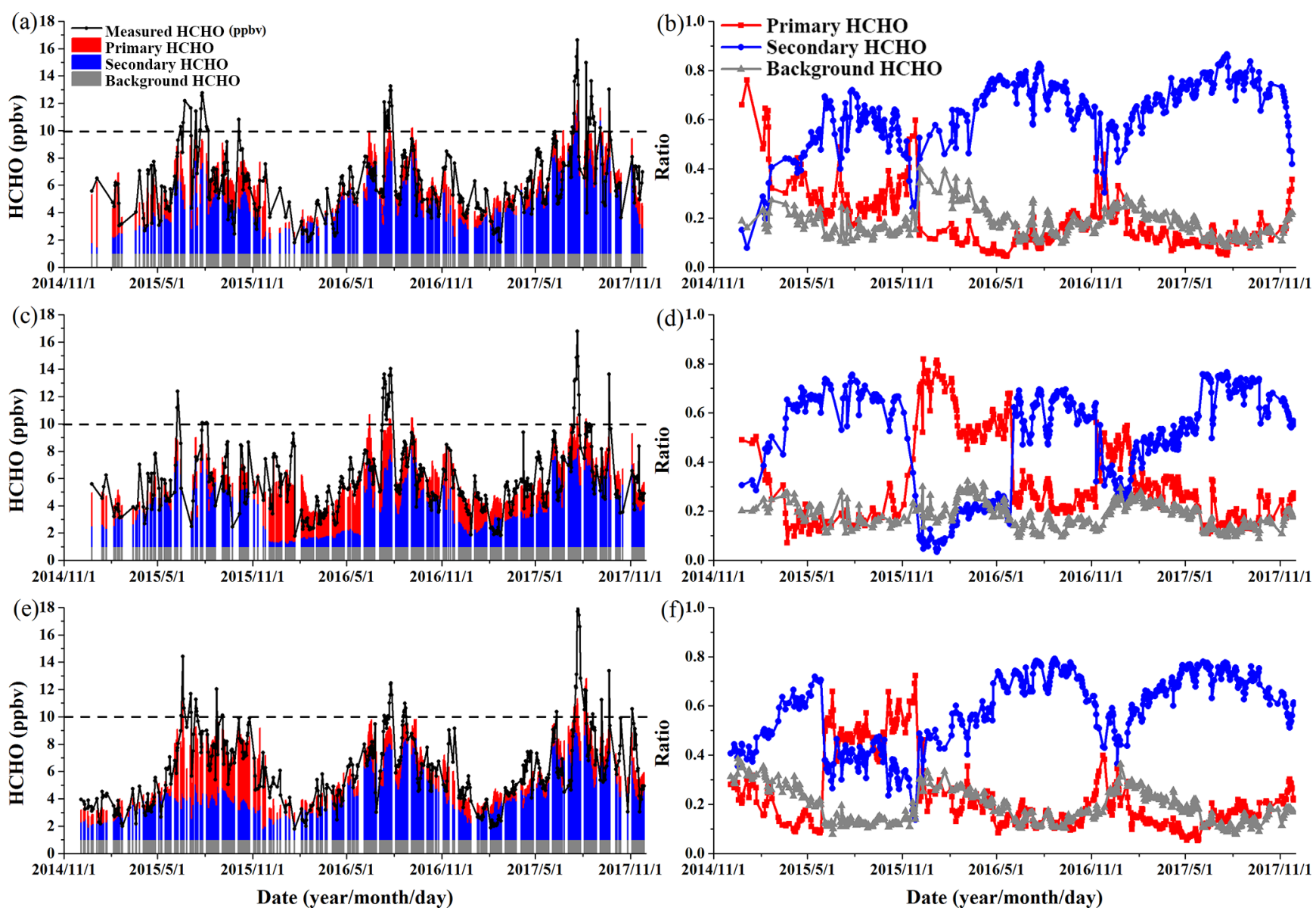

Figure 9. The time series of absolute $(\mathbf{a}, \mathbf{c}, \mathbf{e})$ and relative $(\mathbf{b}, \mathbf{d}, \mathbf{f})$ contributions of primary sources, secondary sources, and background sources to the HCHO concentration from December 2014 to November 2017 at the HK (a, b), PDNA (c, d), and DSL (e, f) sites in Shanghai. Black dashed lines represent the threshold value for $\mathrm{HCHO}$ pollution.

mate the different sources of ambient $\mathrm{HCHO}$. The results in Sect. 3.3 indicate that the main influencing factor for the ambient $\mathrm{HCHO}$ concentration depends on the season. Here we define $\mathrm{HCHO}$ pollution using a $\mathrm{HCHO}$ concentration threshold value of $10 \mathrm{ppbv}$, which is the 95th percentile of all of the observation data. HCHO pollution events mostly occurred in summer, accounting for $81.0 \%, 81.3 \%$, and $95.2 \%$ of all observed pollution events in Nanjing, Hangzhou, and Shanghai, respectively. In summer, HCHO pollution mostly occurred during the periods from 24 to 27 July 2016 and 22 to 27 July 2017 in Nanjing and from 23 to 27 July 2016 and from 20 to 27 July 2017 in Hangzhou. HCHO pollution in Shanghai lasted longer than episodes in Nanjing and Hangzhou: from 10 to 27 July of 2016 and 2017. Moreover, HCHO pollution events were also observed during the period from 23 to 27 August 2015 and from 5 to 24 August 2017 north of the center of Shanghai. In the Shanghai suburbs, three HCHO pollution periods were also observed: (1) from 19 June to 5 July 2015, (2) from 19 to 23 August 2016, and (3) from 4 to 7 August 2017. During HCHO pollution events, sec- ondary formation contributed most to the ambient $\mathrm{HCHO}$ concentration and increased more significantly than the primary $\mathrm{HCHO}$ contribution. Compared with the concentrations before pollution days, secondary $\mathrm{HCHO}$ and primary $\mathrm{HCHO}$ increased by 0.90 and -0.12 ppbv on average in Nanjing, respectively, by 1.33 and $0.21 \mathrm{ppbv}$ in Hangzhou, respectively, and by 1.26 and $0.14 \mathrm{ppbv}$ in Shanghai, respectively. Therefore decreasing VOC emissions, the source of secondary $\mathrm{HCHO}$, would have a more significant effect on controlling HCHO pollution in Nanjing, Hangzhou, and Shanghai.

The industries of Nanjing include the chemical industry, steel plants, and the cement industry (Zheng et al., 2016). In the Nanjing industrial zone, secondary sources of $\mathrm{HCHO}$ were about 4 times larger than primary sources in 2017. Therefore, at industrial sites, decreasing VOC emissions from chemical-related activities is an efficient way to control the ambient HCHO concentration. In Hangzhou, laborintensive industries are the most important parts of industry economics (Zheng et al., 2016). Secondary HCHO concentrations in the eastern suburbs of Hangzhou were highest 
from 2016 to 2017 (Table 1), corresponding to a previous study by B. Lu et al. (2018) which indicated that the largest amount of VOC emissions were measured in the eastern suburbs of Hangzhou and that VOC emissions from furniture manufacturing were the largest source. Secondary HCHO contributed most to ambient $\mathrm{HCHO}$ during the period when it was not effectively controlled (from 2015 to 2017). Considering that industrial manufacturing is developing rather rapidly and that VOC emissions occur from many types of industries, i.e., textile industry, printing, leather manufacturing, and shoemaking (Liu et al., 2008; Khan and Malik, 2014), controlling VOC emissions in Hangzhou will be a huge challenge. Unlike Nanjing and Hangzhou, tertiary industry has played a leading role in Shanghai's economy since 2013, and primary and secondary industries have decreased since 1999 (Chen et al., 2016). However, the HCHO concentration from secondary sources has not been controlled effectively. Decreasing private cars on the road, developing evaporative control regulations, and improving traffic management, which needs to be better suited to local conditions, would help reduce not only VOC emissions but also HCHO emissions, especially in the downtown area (Wang and Zhao, 2008; Liu et al., 2015, 2017).

\section{Summary}

Tropospheric HCHO VCDs derived from OMPS observations were validated using ground-based FTS measurements in Hefei, from 2015 to 2017. The HCHO VCDs observed by OMPS and FTS were in good agreement $(R=0.78)$. Serious HCHO pollution was observed in the YRD region, especially in southwestern Jiangsu Province (e.g., Nanjing, Changzhou, Wuxi, and Suzhou cities), in northern Zhejiang Province (e.g., Hangzhou, Jiaxing, Huzhou, and Ningbo cities), and in Shanghai. Estimating different sources of ambient $\mathrm{HCHO}$ and then formulating control measures adapted to local conditions are effective ways of controlling $\mathrm{HCHO}$ pollution. However, measurements of $\mathrm{HCHO}$ are scarce, both spatially and temporally. In this study, we analyzed primary and secondary contributions to ambient $\mathrm{HCHO}$ using a multiple linear regression based on HCHO observed by OMPS. At the MGQ site in Nanjing, the average relative contributions from primary emissions, secondary formation, and background sources to HCHO from 15 April to 1 May 2015 were 50.5\%, $30.8 \%$, and $18.7 \%$, respectively, which was in good agreement with previous research. Therefore, tropospheric $\mathrm{HCHO}$ columns observed by OMPS can be used to estimate different sources of ambient $\mathrm{HCHO}$.

Primary and secondary contributions to ambient $\mathrm{HCHO}$ were determined in Nanjing, Hangzhou, and Shanghai from 2015 to 2017. Overall, the HCHO concentration from secondary formation contributed most to ambient $\mathrm{HCHO}$ in the megacities in the YRD region and influenced the variation of the ambient HCHO concentration in Hangzhou, Shang- hai, and urban regions of Nanjing. In comparison, at industrial sites of Nanjing, the annual average HCHO concentration from primary emissions decreased significantly from 2015 to 2016 due to energy saving methods and the reduction of energy consumption, and the contribution from secondary formation to the variation of the $\mathrm{HCHO}$ concentration was less significant. At suburban regions in Hangzhou, primary emissions showed a small increasing trend from 2015 to 2017, whereas at urban sites, primary emissions of $\mathrm{HCHO}$ in Shanghai were larger than those in Hangzhou. Seasonally, secondary $\mathrm{HCHO}$ reached a maximum in summer and a minimum in winter. In spring, summer, and autumn, secondary formation played a crucial role in the variation of the HCHO concentration in urban areas of Nanjing, Hangzhou, and Shanghai, whereas in winter, primary emission contributed more to variation of ambient HCHO in Nanjing, Shanghai, and urban areas of Hangzhou. These findings contribute to formulating effective $\mathrm{HCHO}$ pollution control measures. Furthermore, the usability of total HCHO as a proxy of VOC reactivity depends on the timescale utilized. Total $\mathrm{HCHO}$ can be regarded as a proxy for VOC reactivity over a 3-year study period, whereas only secondary $\mathrm{HCHO}$ can be used as a proxy for VOC reactivity over a shorter study period, e.g., in winter. Therefore separating the HCHO contributions from different sources is of great significance in sensitivity studies of $\mathrm{O}_{3}$ production.

Data availability. The data used in this paper is available on request from the corresponding author (chliu81@ustc.edu.cn and qhhu@aiofm.ac.cn).

Supplement. The supplement related to this article is available online at: https://doi.org/10.5194/acp-19-6717-2019-supplement.

Author contributions. WS and CL contributed equally to this study. $\mathrm{CL}$ and $\mathrm{QH}$ designed and supervised the study, and CL also helped retrieve the satellite data. WS wrote the paper. SZ, YS, and WW retrieved the FTS data, and YZ ran the WRF-Chem model. JL supported the project, and $\mathrm{JK}$ contributed to discussions regarding the results.

Competing interests. The authors declare that they have no conflict of interest.

Acknowledgements. This work was supported by National Key Research and Development Program of China (grant nos. 2017YFC0210002, 2018YFC0213104, 2018YFC0213100, and 2016YFC0203302), the National Natural Science Foundation of China (grant nos. 41722501, 91544212, 51778596, and 41575021), and the National High-Resolution Earth Observation Project of China (grant no. 05-Y20A16-9001-15/17-2). The authors 
acknowledge the OMPS project for making the OMPS-NPP Nadir Mapper Earth View Level 1B data product available online. We also thank the Ministry of Environment Protection of the People's Republic of China for making data measured by the atmospheric environment automatic monitoring stations available online.

Review statement. This paper was edited by Min Shao and reviewed by two anonymous referees.

\section{References}

Altshuller, A.: Production of aldehydes as primary emissions and from secondary atmospheric reactions of alkenes and alkanes during the night and early morning hours, Atmos. Environ. AGen, 27, 21-32, https://doi.org/10.1016/0960-1686(93)90067-9, 1993.

Anderson, D., Nicely, J., Salawitch, R., Wolfe, G., Hanisco, T., Dickerson, R., Canty, T., and Li, C.: Evaluation of satellite HCHO retrievals over the tropical western Pacific and United States, 2016 AGU Fall Meeting, San Francisco, USA, 12-15 December 2016, 3-7, 2016.

Anderson, L. G., Lanning, J. A., Barrell, R., Miyagishima, J., Jones, R. H., and Wolfe, P.: Sources and sinks of formaldehyde and acetaldehyde: An analysis of Denver's ambient concentration data, Atmos. Environ., 30, 2113-2123, https://doi.org/10.1016/13522310(95)00175-1, 1996.

Andreae, M. O. and Merlet, P.: Emission of trace gases and aerosols from biomass burning, Global Biogeochem. Cy., 15, 955-966, https://doi.org/10.1029/2000GB001382, 2001.

Barrero, M., Orza, J., Cabello, M., and Cantón, L.: Categorisation of air quality monitoring stations by evaluation of $\mathrm{PM}_{10}$ variability, Sci. Total Environ., 524, 225-236, https://doi.org/10.1016/j.scitotenv.2015.03.138, 2015.

Bovensmann, H., Burrows, J., Buchwitz, M., Frerick, J., Noël, S., Rozanov, V., Chance, K., and Goede, A.: SCIAMACHY: Mission objectives and measurement modes, J. Atmos. Sci., 56, 127-150, https://doi.org/10.1175/15200469(1999)056<0127:SMOAMM>2.0.CO;2, 1999.

Carlier, P., Hannachi, H., and Mouvier, G.: The chemistry of carbonyl compounds in the atmosphere - a review, Atmos. Environ., 20, 2079-2099, https://doi.org/10.1016/0004-6981(86)90304-5, 1986.

Carter, W. P.: Development of ozone reactivity scales for volatile organic compounds, Air \& waste, 44, 881-899, https://doi.org/10.1080/1073161X.1994.10467290, 1994.

Carter, W. P.: Computer modeling of environmental chamber measurements of maximum incremental reactivities of volatile organic compounds, Atmos. Environ., 29, 2513-2527, https://doi.org/10.1016/1352-2310(95)00150-W, 1995.

Chen, J., Judd, B., and Hawken, S.: Adaptive reuse of industrial heritage for cultural purposes in Beijing, Shanghai and Chongqing, Structural Survey, 34, 331-350, https://doi.org/10.1108/SS-112015-0052, 2016.

Crutzen, P. J.: The role of $\mathrm{NO}$ and $\mathrm{NO}_{2}$ in the chemistry of the troposphere and stratosphere, Ann. Rev. Earth Pl. Sc., 7, 443-472, https://doi.org/10.1146/annurev.ea.07.050179.002303, 1979.
De Smedt, I., Müller, J.-F., Stavrakou, T., van der A, R., Eskes, H., and Van Roozendael, M.: Twelve years of global observations of formaldehyde in the troposphere using GOME and SCIAMACHY sensors, Atmos. Chem. Phys., 8, 4947-4963, https://doi.org/10.5194/acp-8-4947-2008, 2008.

De Smedt, I., Van Roozendael, M., Stavrakou, T., Müller, J.-F., Lerot, C., Theys, N., Valks, P., Hao, N., and van der A, R.: Improved retrieval of global tropospheric formaldehyde columns from GOME-2/MetOp-A addressing noise reduction and instrumental degradation issues, Atmos. Meas. Tech., 5, 2933-2949, https://doi.org/10.5194/amt-5-2933-2012, 2012.

De Smedt, I., Stavrakou, T., Hendrick, F., Danckaert, T., Vlemmix, T., Pinardi, G., Theys, N., Lerot, C., Gielen, C., Vigouroux, C., Hermans, C., Fayt, C., Veefkind, P., Müller, J.-F., and Van Roozendael, M.: Diurnal, seasonal and long-term variations of global formaldehyde columns inferred from combined OMI and GOME-2 observations, Atmos. Chem. Phys., 15, 12519-12545, https://doi.org/10.5194/acp-15-12519-2015, 2015.

De Smedt, I., Theys, N., Yu, H., Danckaert, T., Lerot, C., Compernolle, S., Van Roozendael, M., Richter, A., Hilboll, A., Peters, E., Pedergnana, M., Loyola, D., Beirle, S., Wagner, T., Eskes, H., van Geffen, J., Boersma, K. F., and Veefkind, P.: Algorithm theoretical baseline for formaldehyde retrievals from S5P TROPOMI and from the QA4ECV project, Atmos. Meas. Tech., 11, 23952426, https://doi.org/10.5194/amt-11-2395-2018, 2018.

Dong, D., Shao, M., Li, Y., Lu, S., Wang, Y., Ji, Z., and Tang, D.: Carbonyl emissions from heavy-duty diesel vehicle exhaust in China and the contribution to ozone formation potential, J. Environ. Sci., 26, 122-128, https://doi.org/10.1016/S10010742(13)60387-3, 2014.

Duan, J., Tan, J., Yang, L., Wu, S., and Hao, J.: Concentration, sources and ozone formation potential of volatile organic compounds (VOCs) during ozone episode in Beijing, Atmos. Res., 88, 25-35, https://doi.org/10.1016/j.atmosres.2007.09.004, 2008.

Duncan, B. N., Yoshida, Y., Olson, J. R., Sillman, S., Martin, R. V., Lamsal, L., Hu, Y., Pickering, K. E., Retscher, C., Allen, D. J., and Crawford, J. H.: Application of OMI observations to a space-based indicator of NOx and VOC controls on surface ozone formation, Atmos. Environ., 44, 2213-2223, https://doi.org/10.1016/j.atmosenv.2010.03.010, 2010.

Finlayson-Pitts, B. J. and Pitts Jr., J. N.: Chemistry of the upper and lower atmosphere: theory, experiments, and applications, Elsevier, Irvine, California, USA, 1999.

Flynn, L., Long, C., Wu, X., Evans, R., Beck, C., Petropavlovskikh, I., McConville, G., Yu, W., Zhang, Z., and Niu, J.: Performance of the ozone mapping and profiler suite (OMPS) products, J. Geophys. Res.-Atmos., 119, 6181-6195, https://doi.org/10.1002/2013JD020467, 2014.

Friedfeld, S., Fraser, M., Ensor, K., Tribble, S., Rehle, D., Leleux, D., and Tittel, F.: Statistical analysis of primary and secondary atmospheric formaldehyde, Atmos. Environ., 36, 4767-4775, https://doi.org/10.1016/S1352-2310(02)00558-7, 2002.

Fung, K. and Grosjean, D.: Determination of nanogram amounts of carbonyls as 2, 4-dinitrophenylhydrazones by highperformance liquid chromatography, Anal. Chem., 53, 168-171, https://doi.org/10.1021/ac00225a009, 1981.

Gao, J., Zhu, B., Xiao, H., Kang, H., Hou, X., and Shao, P.: A case study of surface ozone source apportionment during a high con- 
centration episode, under frequent shifting wind conditions over the Yangtze River Delta, China, Sci. Total Environ., 544, 853863, https://doi.org/10.1016/j.scitotenv.2015.12.039, 2016.

Garcia, A. R., Volkamer, R., Molina, L. T., Molina, M. J., Samuelson, J., Mellqvist, J., Galle, B., Herndon, S. C., and Kolb, C. E.: Separation of emitted and photochemical formaldehyde in Mexico City using a statistical analysis and a new pair of gas-phase tracers, Atmos. Chem. Phys., 6, 4545-4557, https://doi.org/10.5194/acp-6-4545-2006, 2006.

González Abad, G., Liu, X., Chance, K., Wang, H., Kurosu, T. P., and Suleiman, R.: Updated Smithsonian Astrophysical Observatory Ozone Monitoring Instrument (SAO OMI) formaldehyde retrieval, Atmos. Meas. Tech., 8, 19-32, https://doi.org/10.5194/amt-8-19-2015, 2015.

González Abad, G., Vasilkov, A., Seftor, C., Liu, X., and Chance, K.: Smithsonian Astrophysical Observatory Ozone Mapping and Profiler Suite (SAO OMPS) formaldehyde retrieval, Atmos. Meas. Tech., 9, 2797-2812, https://doi.org/10.5194/amt-9-27972016, 2016.

Haagen-Smit, A. J.: The air pollution problem in Los Angeles, Engineering and Science, 14, 7-13, 1950.

He, J., Gong, S., Yu, Y., Yu, L., Wu, L., Mao, H., Song, C., Zhao, S., Liu, H., and Li, X.: Air pollution characteristics and their relation to meteorological conditions during 20142015 in major Chinese cities, Environ. Pollut., 223, 484-496, https://doi.org/10.1016/j.envpol.2017.01.050, 2017.

Hoekman, S. K.: Speciated measurements and calculated reactivities of vehicle exhaust emissions from conventional and reformulated gasolines, Environ. Sci. Technol., 26, 1206-1216, https://doi.org/10.1021/es50002a610, 1992.

Holzinger, R., Warneke, C., Hansel, A., Jordan, A., Lindinger, W., Scharffe, D. H., Schade, G., and Crutzen, P. J.: Biomass burning as a source of formaldehyde, acetaldehyde, methanol, acetone, acetonitrile, and hydrogen cyanide, Geophys. Res. Lett., 26, 1161-1164, https://doi.org/10.1029/1999GL900156, 1999.

Hong, Q., Liu, C., Chan, K. L., Hu, Q., Xie, Z., Liu, H., Si, F., and Liu, J.: Ship-based MAX-DOAS measurements of tropospheric $\mathrm{NO}_{2}, \mathrm{SO}_{2}$, and $\mathrm{HCHO}$ distribution along the Yangtze River, Atmos. Chem. Phys., 18, 5931-5951, https://doi.org/10.5194/acp18-5931-2018, 2018.

Jones, N. B., Riedel, K., Allan, W., Wood, S., Palmer, P. I., Chance, K., and Notholt, J.: Long-term tropospheric formaldehyde concentrations deduced from ground-based fourier transform solar infrared measurements, Atmos. Chem. Phys., 9, 7131-7142, https://doi.org/10.5194/acp-9-7131-2009, 2009.

Karl, T., Jobson, T., Kuster, W. C., Williams, E., Stutz, J., Shetter, R., Hall, S. R., Goldan, P., Fehsenfeld, F., and Lindinger, W.: Use of proton-transfer-reaction mass spectrometry to characterize volatile organic compound sources at the La Porte super site during the Texas Air Quality Study 2000, J. Geophys. Res.-Atmos., 108, 4508, https://doi.org/10.1029/2002JD003333, 2003.

Kawamura, K., Steinberg, S., and Kaplan, I. R.: Homologous series of $\mathrm{C} 1-\mathrm{C} 10$ monocarboxylic acids and $\mathrm{C} 1-\mathrm{C} 6$ carbonyls in Los Angeles air and motor vehicle exhausts, Atmos. Environ., 34, 4175-4191, https://doi.org/10.1016/S1352-2310(00)00212$0,2000$.

Kean, A. J., Grosjean, E., Grosjean, D., and Harley, R. A.: On-road measurement of carbonyls in California light-duty vehicle emissions, Environ. Sci. Technol., 35, 4198-4204, https://doi.org/10.1021/es010814v, 2001.

Khan, S. and Malik, A.: Environmental and health effects of textile industry wastewater, in: Environmental deterioration and human health, Springer, India, 55-71, 2014.

Klimont, Z., Streets, D. G., Gupta, S., Cofala, J., Lixin, F., and Ichikawa, Y.: Anthropogenic emissions of non-methane volatile organic compounds in China, Atmos. Environ., 36, 1309-1322, https://doi.org/10.1016/S1352-2310(01)00529-5, 2002.

Kurylo, M. J.: Network for the detection of stratospheric change, Remote Sensing of Atmospheric Chemistry, 1491, 168-175, https://doi.org/10.1117/12.46658, 1991.

Lawson, D., Biermann, H., Tuazon, E., Winer, A., Mackay, G., Schiff, H., Kok, G., Dasgupta, P., and Fung, K.: Formaldehyde measurement methods evaluation and ambient concentrations during the carbonaceous species methods comparison study, Aerosol Sci. Tech., 12, 64-76, https://doi.org/10.1080/02786829008959326, 1990.

Lee, C., Richter, A., Lee, H., Kim, Y. J., Burrows, J. P., Lee, Y. G., and Choi, B. C.: Impact of transport of sulfur dioxide from the Asian continent on the air quality over Korea during May 2005, Atmos. Environ., 42, 1461-1475, https://doi.org/10.1016/j.atmosenv.2007.11.006, 2008.

Lee, M., Heikes, B. G., Jacob, D. J., Sachse, G., and Anderson, B. Hydrogen peroxide, organic hydroperoxide, and formaldehyde as primary pollutants from biomass burning, J. Geophys. Res.Atmos., 102, 1301-1309, https://doi.org/10.1029/96JD01709, 1997.

Levy, H.: Normal atmosphere: Large radical and formaldehyde concentrations predicted, Science, 173, 141-143, https://doi.org/10.1126/science.173.3992.141, 1971.

Li, C., Joiner, J., Krotkov, N. A., and Dunlap, L.: A new method for global retrievals of HCHO total columns from the Suomi National Polar-orbiting Partnership Ozone Mapping and Profiler Suite, Geophys. Res. Lett., 42, 2515-2522, https://doi.org/10.1002/2015GL063204, 2015.

Li, H., Li, L., Huang, C., An, J.-Y., Yan, R.-S., Huang, H.Y., Wang, Y.-J., Lu, Q., Wang, Q., Lou, S.-R., Wang, H.L., Zhou, M., Tao, S.-K., Qiao, L.-P., And Chen, M.-H.: Ozone source apportionment at urban area during a typical photochemical pollution episode in the summer of 2013 in the Yangtze River Delta, Huan Jing Ke Xue, 36, 1-10, https://doi.org/10.13227/j.hjkx.2015.01.001, 2015.

Li, P., De Marco, A., Feng, Z., Anav, A., Zhou, D., and Paoletti, E.: Nationwide ground-level ozone measurements in China suggest serious risks to forests, Environ. Pollut., 237, 803-813, https://doi.org/10.1016/j.envpol.2017.11.002, 2018.

Li, Y., Shao, M., Lu, S., Chang, C.-C., and Dasgupta, P. K.: Variations and sources of ambient formaldehyde for the 2008 Beijing Olympic games, Atmos. Environ., 44, 2632-2639, https://doi.org/10.1016/j.atmosenv.2010.03.045, 2010.

Liu, C., Zhang, C., Mu, Y., Liu, J., and Zhang, Y.: Emission of volatile organic compounds from domestic coal stove with the actual alternation of flaming and smoldering combustion processes, Environ. Pollut., 221, 385-391, https://doi.org/10.1016/j.envpol.2016.11.089, 2017.

Liu, H., Man, H., Tschantz, M., Wu, Y., He, K., and Hao, J.: VOC from vehicular evaporation emissions: status and 
control strategy, Environ. Sci. Technol., 49, 14424-14431, https://doi.org/10.1021/acs.est.5b04064, 2015.

Liu, H., Liu, C., Xie, Z., Li, Y., Huang, X., Wang, S., Xu, J., and Xie, P.: A paradox for air pollution controlling in China revealed by "APEC Blue" and "Parade Blue", Sci. Rep., 6, 34408, https://doi.org/10.1038/srep34408, 2016.

Liu, H., Liu, S., Xue, B., Lv, Z., Meng, Z., Yang, X., Xue, T., Yu, Q., and He, K.: Ground-level ozone pollution and its health impacts in China, Atmos. Environ., 173, 223-230, https://doi.org/10.1016/j.atmosenv.2017.11.014, 2018.

Liu, Y., Shao, M., Lu, S., Chang, C.-C., Wang, J.-L., and Chen, G.: Volatile Organic Compound (VOC) measurements in the Pearl River Delta (PRD) region, China, Atmos. Chem. Phys., 8, 15311545, https://doi.org/10.5194/acp-8-1531-2008, 2008.

Lu, B., Huang, C., Lu, Q., Yang, Q., Jing, B., Xia, Y., Tang, W., and $\mathrm{Gu}, \mathrm{Z}$.: Emission Inventory and Pollution Characteristics of Industrial VOCs in Hangzhou, China, Huan Jing Ke Xue, 39, 533-542, https://doi.org/10.13227/j.hjkx.201706062, 2018.

Lu, X., Hong, J., Zhang, L., Cooper, O. R., Schultz, M. G., Xu, X., Wang, T., Gao, M., Zhao, Y., and Zhang, Y.: Severe surface ozone pollution in China: a global perspective, Environ. Sci. Technol. Lett., 5, 487-494, https://doi.org/10.1021/acs.estlett.8b00366, 2018.

Luecken, D., Hutzell, W., and Gipson, G.: Development and analysis of air quality modeling simulations for hazardous air pollutants, Atmos. Environ., 40, 5087-5096, https://doi.org/10.1016/j.atmosenv.2005.12.044, 2006.

Lui, K. H., Ho, S. S. H., Louie, P. K. K., Chan, C. S., Lee, S. C., Hu, D., Chan, P. W., Lee, J. C. W., and Ho, K. F.: Seasonal behavior of carbonyls and source characterization of formaldehyde (HCHO) in ambient air, Atmos. Environ., 152, 51-60, https://doi.org/10.1016/j.atmosenv.2016.12.004, 2017.

Luo, M., Beer, R., Jacob, D. J., Logan, J. A., and Rodgers, C.: Simulated observation of tropospheric ozone and $\mathrm{CO}$ with the Tropospheric Emission Spectrometer (TES) satellite instrument, J. Geophys. Res.-Atmos., 107, 4270, https://doi.org/10.1029/2001JD000804, 2002.

Luo, M., Rinsland, C., Fisher, B., Sachse, G., Diskin, G., Logan, J., Worden, H., Kulawik, S., Osterman, G., and Eldering, A.: TES carbon monoxide validation with DACOM aircraft measurements during INTEX-B 2006, J. Geophys. Res.-Atmos., 112, D24S48, https://doi.org/10.1029/2007JD008803, 2007.

Ma, Y., Diao, Y., Zhang, B., Wang, W., Ren, X., Yang, D., Wang, M., Shi, X., and Zheng, J.: Detection of formaldehyde emissions from an industrial zone in the Yangtze River Delta region of China using a proton transfer reaction ion-drift chemical ionization mass spectrometer, Atmos. Meas. Tech., 9, 6101-6116, https://doi.org/10.5194/amt-9-6101-2016, 2016.

Martin, R., Parrish, D., Ryerson, T., Nicks, D., Chance, K., Kurosu, T., Jacob, D. J., Sturges, E., Fried, A., and Wert, B.: Evaluation of GOME satellite measurements of tropospheric $\mathrm{NO}_{2}$ and $\mathrm{HCHO}$ using regional data from aircraft campaigns in the southeastern United States, J. Geophys. Res.-Atmos., 109, D24307, https://doi.org/10.1029/2004jd004869, 2004.

Marvin, M. R., Wolfe, G. M., Salawitch, R. J., Canty, T. P., Roberts, S. J., Travis, K. R., Aikin, K. C., de Gouw, J. A., Graus, M., and Hanisco, T. F.: Impact of evolving isoprene mechanisms on simulated formaldehyde: An inter-comparison supported by in situ observations from SENEX, Atmos. Environ., 164, 325-336, https://doi.org/10.1016/j.atmosenv.2017.05.049, 2017.

Munro, R., Lang, R., Klaes, D., Poli, G., Retscher, C., Lindstrot, R., Huckle, R., Lacan, A., Grzegorski, M., Holdak, A., Kokhanovsky, A., Livschitz, J., and Eisinger, M.: The GOME2 instrument on the Metop series of satellites: instrument design, calibration, and level 1 data processing - an overview, Atmos. Meas. Tech., 9, 1279-1301, https://doi.org/10.5194/amt-9-12792016, 2016.

Notholt, J., Meier, A., and Peil, S.: Total column densities of tropospheric and stratospheric trace gases in the undisturbed Arctic summer atmosphere, J. Atmos. Chem., 20, 311-332, https://doi.org/10.1007/BF00694500, 1995.

Pagano, T. S., Broberg, S., Aumann, H. H., Elliott, D., Manning, E., and Strow, L.: Performance status of the Atmospheric Infrared Sounder ten years after launch, Multispectral, Hyperspectral, and Ultraspectral Remote Sensing Technology, Techniques and Applications IV, 30-31 October 2012, Kyoto, Japan, 8527-2, 2012.

Palmer, P. I., Jacob, D. J., Fiore, A. M., Martin, R. V., Chance, K., and Kurosu, T. P.: Mapping isoprene emissions over North America using formaldehyde column observations from space, J. Geophys. Res.-Atmos., 108, 4180, https://doi.org/10.1029/2002JD002153, 2003.

Platt, U. and Perner, D.: Direct measurements of atmospheric $\mathrm{CH}_{2} \mathrm{O}, \mathrm{HNO}_{2}, \mathrm{O}_{3}, \mathrm{NO}_{2}$, and $\mathrm{SO}_{2}$ by differential optical absorption in the near UV, J. Geophys. Res.-Oceans, 85, 7453-7458, https://doi.org/10.1029/JC085iC12p07453, 1980.

Qiu, K., Yang, L., Lin, J., Wang, P., Yang, Y., Ye, D., and Wang, L.: Historical industrial emissions of nonmethane volatile organic compounds in China for the period of 1980-2010, Atmos. Environ., 86, 102-112, https://doi.org/10.1016/j.atmosenv.2013.12.026, 2014.

Reuter, M., Bovensmann, H., Buchwitz, M., Burrows, J., Connor, B., Deutscher, N. M., Griffith, D., Heymann, J., KeppelAleks, G., and Messerschmidt, J.: Retrieval of atmospheric $\mathrm{CO}_{2}$ with enhanced accuracy and precision from SCIAMACHY: Validation with FTS measurements and comparison with model results, J. Geophys. Res.-Atmos., 116, D04301, https://doi.org/10.1029/2010JD015047, 2011.

Reyes, F., Grutter, M., Jazcilevich, A., and González-Oropeza, R.: Tecnical Note: Analysis of non-regulated vehicular emissions by extractive FTIR spectrometry: tests on a hybrid car in Mexico City, Atmos. Chem. Phys., 6, 5339-5346, https://doi.org/10.5194/acp-6-5339-2006, 2006.

Rohde, R. A. and Muller, R. A.: Air pollution in China: mapping of concentrations and sources, Plos One, 10, e0135749, https://doi.org/10.1371/journal.pone.0135749, 2015.

Russell, A., Milford, J., Bergin, M., McBride, S., McNair, L., Yang, Y., Stockwell, W., and Croes, B.: Urban ozone control and atmospheric reactivity of organic gases, Science, 269, 491-495, https://doi.org/10.1126/science.269.5223.491, 1995.

Seftor, C., Jaross, G., Kowitt, M., Haken, M., Li, J., and Flynn, L.: Postlaunch performance of the Suomi National Polar-orbiting Partnership Ozone Mapping and Profiler Suite (OMPS) nadir sensors, J. Geophys. Res.-Atmos., 119, 44134428, https://doi.org/10.1002/2013JD020472, 2014.

Seinfeld, J. H. and Pandis, S. N.: Atmospheric chemistry and physics: from air pollution to climate change, John Wiley \& Sons, California, USA, 2016. 
Shah, S., Tuinder, O. N. E., van Peet, J. C. A., de Laat, A. T. J., and Stammes, P.: Evaluation of SCIAMACHY Level-1 data versions using nadir ozone profile retrievals in the period 2003-2011, Atmos. Meas. Tech., 11, 2345-2360, https://doi.org/10.5194/amt11-2345-2018, 2018.

Shi, M., Wu, H., Zhang, S., Li, H., Yang, T., Liu, W., and Liu, H.: Weekly cycle of magnetic characteristics of the daily $\mathrm{PM}_{2.5}$ and $\mathrm{PM}_{2.5-10}$ in Beijing, China, Atmos. Environ., 98, 357-367, https://doi.org/10.1016/j.atmosenv.2014.08.079, 2014.

Su, W., Liu, C., Hu, Q., Fan, G., Xie, Z., Huang, X., Zhang, T., Chen, Z., Dong, Y., Ji, X., Liu, H., Wang, Z., and Liu, J.: Characterization of ozone in the lower troposphere during the 2016 G20 conference in Hangzhou, Sci. Rep., 7, 17368, https://doi.org/10.1038/s41598-017-17646-x, 2017.

Sun, Y., Palm, M., Weinzierl, C., Petri, C., Notholt, J., Wang, Y., and Liu, C.: Technical note: Sensitivity of instrumental line shape monitoring for the ground-based high-resolution FTIR spectrometer with respect to different optical attenuators, Atmos. Meas. Tech., 10, 989-997, https://doi.org/10.5194/amt-10-9892017, 2017.

Sun, Y., Liu, C., Palm, M., Vigouroux, C., Notholt, J., Hu, Q., Jones, N., Wang, W., Su, W., Zhang, W., Shan, C., Tian, Y., Xu, X., De Mazière, M., Zhou, M., and Liu, J.: Ozone seasonal evolution and photochemical production regime in the polluted troposphere in eastern China derived from high-resolution Fourier transform spectrometry (FTS) observations, Atmos. Chem. Phys., 18, 14569-14583, https://doi.org/10.5194/acp-18-14569-2018, 2018.

Tang, G., Wang, Y., Li, X., Ji, D., Hsu, S., and Gao, X.: Spatialtemporal variations in surface ozone in Northern China as observed during 2009-2010 and possible implications for future air quality control strategies, Atmos. Chem. Phys., 12, 2757-2776, https://doi.org/10.5194/acp-12-2757-2012, 2012.

Tian, Y., Sun, Y., Liu, C., Wang, W., Shan, C., Xu, X., and Hu, Q.: Characterisation of methane variability and trends from nearinfrared solar spectra over Hefei, China, Atmos. Environ., 173, 198-209, https://doi.org/10.1016/j.atmosenv.2017.11.001, 2018.

Vigouroux, C., Hendrick, F., Stavrakou, T., Dils, B., De Smedt, I., Hermans, C., Merlaud, A., Scolas, F., Senten, C., Vanhaelewyn, G., Fally, S., Carleer, M., Metzger, J.-M., Müller, J.-F., Van Roozendael, M., and De Mazière, M.: Ground-based FTIR and MAX-DOAS observations of formaldehyde at Réunion Island and comparisons with satellite and model data, Atmos. Chem. Phys., 9, 9523-9544, https://doi.org/10.5194/acp-9-9523-2009, 2009.

Volkamer, R., Sheehy, P., Molina, L. T., and Molina, M. J.: Oxidative capacity of the Mexico City atmosphere - Part 1: A radical source perspective, Atmos. Chem. Phys., 10, 6969-6991, https://doi.org/10.5194/acp-10-6969-2010, 2010.

Wang, D., Zhou, B., Fu, Q., Zhao, Q., Zhang, Q., Chen, J., Yang, X., Duan, Y., and Li, J.: Intense secondary aerosol formation due to strong atmospheric photochemical reactions in summer: observations at a rural site in eastern Yangtze River Delta of China, Sci. Total Environ., 571, 1454-1466, https://doi.org/10.1016/j.scitotenv.2016.06.212, 2016.

Wang, M., Chen, W., Shao, M., Lu, S., Zeng, L., and Hu, M.: Investigation of carbonyl compound sources at a rural site in the Yangtze River Delta region of China, J. Environ. Sci., 28, 128136, https://doi.org/10.1016/j.jes.2014.12.001, 2015.
Wang, P. and Zhao, W.: Assessment of ambient volatile organic compounds (VOCs) near major roads in urban Nanjing, China, Atmos. Res., 89, 289-297, https://doi.org/10.1016/j.atmosres.2008.03.013, 2008.

Wang, Q., Geng, C., Lu, S., Chen, W., and Shao, M.: Emission factors of gaseous carbonaceous species from residential combustion of coal and crop residue briquettes, Front. Env. Sci. Eng., 7, 66-76, https://doi.org/10.1007/s11783-012-0428-5, 2013.

Wang, T., Xue, L., Brimblecombe, P., Lam, Y. F., Li, L., and Zhang, L.: Ozone pollution in China: A review of concentrations, meteorological influences, chemical precursors, and effects, Sci. Total Environ., 575, 1582-1596, https://doi.org/10.1016/j.scitotenv.2016.10.081, 2017.

Wang, W., Tian, Y., Liu, C., Sun, Y., Liu, W., Xie, P., Liu, J., Xu, J., Morino, I., Velazco, V. A., Griffith, D. W. T., Notholt, J., and Warneke, T.: Investigating the performance of a greenhouse gas observatory in Hefei, China, Atmos. Meas. Tech., 10, 26272643, https://doi.org/10.5194/amt-10-2627-2017, 2017.

Wang, W.-N., Cheng, T.-H., Gu, X.-F., Chen, H., Guo, H., Wang, Y., Bao, F.-W., Shi, S.-Y., Xu, B.-R., and Zuo, X.: Assessing spatial and temporal patterns of observed ground-level ozone in China, Sci. Rep.-UK, 7, 3651, https://doi.org/10.1038/s41598017-03929-w, 2017.

Wang, X. and Mauzerall, D. L.: Evaluating impacts of air pollution in China on public health: implications for future air pollution and energy policies, Atmos. Environ., 40, 1706-1721, https://doi.org/10.1016/j.atmosenv.2005.10.066, 2006.

Wang, Y., Beirle, S., Lampel, J., Koukouli, M., De Smedt, I., Theys, N., Li, A., Wu, D., Xie, P., Liu, C., Van Roozendael, M., Stavrakou, T., Müller, J.-F., and Wagner, T.: Validation of OMI, GOME-2A and GOME-2B tropospheric $\mathrm{NO}_{2}, \mathrm{SO}_{2}$ and $\mathrm{HCHO}$ products using MAX-DOAS observations from 2011 to 2014 in Wuxi, China: investigation of the effects of priori profiles and aerosols on the satellite products, Atmos. Chem. Phys., 17, 50075033, https://doi.org/10.5194/acp-17-5007-2017, 2017.

Wang, Y., Du, H., Xu, Y., Lu, D., Wang, X., and Guo, Z.: Temporal and spatial variation relationship and influence factors on surface urban heat island and ozone pollution in the Yangtze River Delta, China, Sci. Total Environ., 631, 921-933, https://doi.org/10.1016/j.scitotenv.2018.03.050, 2018.

Warneke, C., De Gouw, J., Goldan, P., Kuster, W., Williams, E., Lerner, B., Jakoubek, R., Brown, S., Stark, H., and Aldener, M.: Comparison of daytime and nighttime oxidation of biogenic and anthropogenic VOCs along the New England coast in summer during New England Air Quality Study 2002, J. Geophys. Res.Atmos., 109, D10309, https://doi.org/10.1029/2003JD004424, 2004.

Wei, W., Wang, S., Chatani, S., Klimont, Z., Cofala, J., and Hao, J.: Emission and speciation of non-methane volatile organic compounds from anthropogenic sources in China, Atmos. Environ., 42, 4976-4988, https://doi.org/10.1016/j.atmosenv.2008.02.044, 2008.

Williams, R. L., Lipari, F., and Potter, R. A.: Formaldehyde, melhanol and hydrocarbon emissions from methanolfueled cars, J. Air Waste Manage., 40, 747-756, https://doi.org/10.1080/10473289.1990.10466720, 1990.

Witte, J., Duncan, B., Douglass, A., Kurosu, T., Chance, K., and Retscher, C.: The unique OMI $\mathrm{HCHO} / \mathrm{NO}_{2}$ feature during the 2008 Beijing Olympics: Implications for 
ozone production sensitivity, Atmos. Environ., 45, 3103-3111, https://doi.org/10.1016/j.atmosenv.2011.03.015, 2011.

World Health Organization: Burden of disease from the joint effects of Household and Ambient Air Pollution for 2012, available at: http://www.who.int/phe/health_topics/outdoorair/ databases/AP_jointeffect_BoD_results_March2014.pdf (last access: 10 October 2018), 2014a.

World Health Organization: WHO methods and data sources for country-level causes of death 2000-2012, available at: http:// www.who.int/healthinfo/statistics/GlobalCOD_method.pdf (last access: 10 October 2018), 2014b.

Wu, X., Huang, W., Zhang, Y., Zheng, C., Jiang, X., Gao, X., and Cen, K.: Characteristics and uncertainty of industrial VOCs emissions in China, Aerosol Air Qual. Res., 15, 1045-1058, https://doi.org/10.4209/aaqr.2014.10.0236, 2015.

Yamamori, M., Kagawa, A., Kasai, Y., Mizutani, K., Murayama, Y., Sugita, T., Irie, H., and Nakajima, H.: Validation of ILASII version $1.4 \mathrm{O}_{3}, \mathrm{HNO}_{3}$, and temperature data through comparison with ozonesonde, ground-based FTS, and lidar measurements in Alaska, J. Geophys. Res.-Atmos., 111, D11S08, https://doi.org/10.1029/2005JD006438, 2006.

Yang, G., Wang, Y., Zeng, Y., Gao, G. F., Liang, X., Zhou, M., Wan, X., Yu, S., Jiang, Y., and Naghavi, M.: Rapid health transition in China, 1990-2010: findings from the Global Burden of Disease Study 2010, Lancet, 381, 1987-2015, https://doi.org/10.1016/S0140-6736(13)61097-1, 2013.

Yang, W., Li, J., Wang, M., Sun, Y., and Wang, Z.: A Case Study of Investigating Secondary Organic Aerosol Formation Pathways in Beijing using an Observation-based SOA Box Model, Aerosol Air Qual. Res., 18, 1606-1616, https://doi.org/10.4209/aaqr.2017.10.0415, 2018.

Yuan, T., Cheng, L., You Wen, S., Hua, X. P., Wei, W., Qing, L. W., Guo, L. J., Ang, L., Zhi, H. R., and Yi, Z.: Retrieval of Atmospheric $\mathrm{CO}_{2}$ and $\mathrm{CH}_{4}$ Variations Using Ground-Based High Resolution Fourier Transform Infrared Spectra, J. Spectrosc., 2015, 736382, https://doi.org/10.1155/2015/736382, 2015.

Yurganov, L., McMillan, W., Grechko, E., and Dzhola, A.: Analysis of global and regional $\mathrm{CO}$ burdens measured from space between 2000 and 2009 and validated by ground-based solar tracking spectrometers, Atmos. Chem. Phys., 10, 3479-3494, https://doi.org/10.5194/acp-10-3479-2010, 2010.
Zheng, J., Ma, Y., Chen, M., Zhang, Q., Wang, L., Khalizov, A. F., Yao, L., Wang, Z., Wang, X., and Chen, L.: Measurement of atmospheric amines and ammonia using the high resolution time-of-flight chemical ionization mass spectrometry, Atmos. Environ., 102, 249-259, https://doi.org/10.1016/j.atmosenv.2014.12.002, 2015.

Zheng, J., Jiang, P., Qiao, W., Zhu, Y., and Kennedy, E.: Analysis of air pollution reduction and climate change mitigation in the industry sector of Yangtze River Delta in China, J. Clean. Prod., 114, 314-322, https://doi.org/10.1016/j.jclepro.2015.07.011, 2016.

Zhu, L., Jacob, D. J., Kim, P. S., Fisher, J. A., Yu, K., Travis, K. R., Mickley, L. J., Yantosca, R. M., Sulprizio, M. P., De Smedt, I., González Abad, G., Chance, K., Li, C., Ferrare, R., Fried, A., Hair, J. W., Hanisco, T. F., Richter, D., Jo Scarino, A., Walega, J., Weibring, P., and Wolfe, G. M.: Observing atmospheric formaldehyde ( $\mathrm{HCHO}$ ) from space: validation and intercomparison of six retrievals from four satellites (OMI, GOME2A, GOME2B, OMPS) with SEAC ${ }^{4}$ RS aircraft observations over the southeast US, Atmos. Chem. Phys., 16, 1347713490, https://doi.org/10.5194/acp-16-13477-2016, 2016.

Zhu, L., Jacob, D. J., Keutsch, F. N., Mickley, L. J., Scheffe, R., Strum, M., Gonzalez Abad, G., Chance, K., Yang, K., Rappengluck, B., Millet, D. B., Baasandorj, M., Jaegle, L., and Shah, V.: Formaldehyde (HCHO) As a Hazardous Air Pollutant: Mapping Surface Air Concentrations from Satellite and Inferring Cancer Risks in the United States, Environ. Sci. Technol., 51, 5650-5657, https://doi.org/10.1021/acs.est.7b01356, 2017a.

Zhu, L., Mickley, L. J., Jacob, D. J., Marais, E. A., Sheng, J., Hu, L., González Abad, G., and Chance, K.: Long-term (2005-2014) trends in formaldehyde $(\mathrm{HCHO})$ columns across North America as seen by the OMI satellite instrument: Evidence of changing emissions of volatile organic compounds, Geophys. Res. Lett., 44, 7079-7086, https://doi.org/10.1002/2017GL073859, 2017b.

Ziemke, J., Chandra, S., and Bhartia, P.: "Cloud slicing": A new technique to derive upper tropospheric ozone from satellite measurements, J. Geophys. Res.-Atmos., 106, 9853-9867, https://doi.org/10.1029/2000JD900768, 2001. 